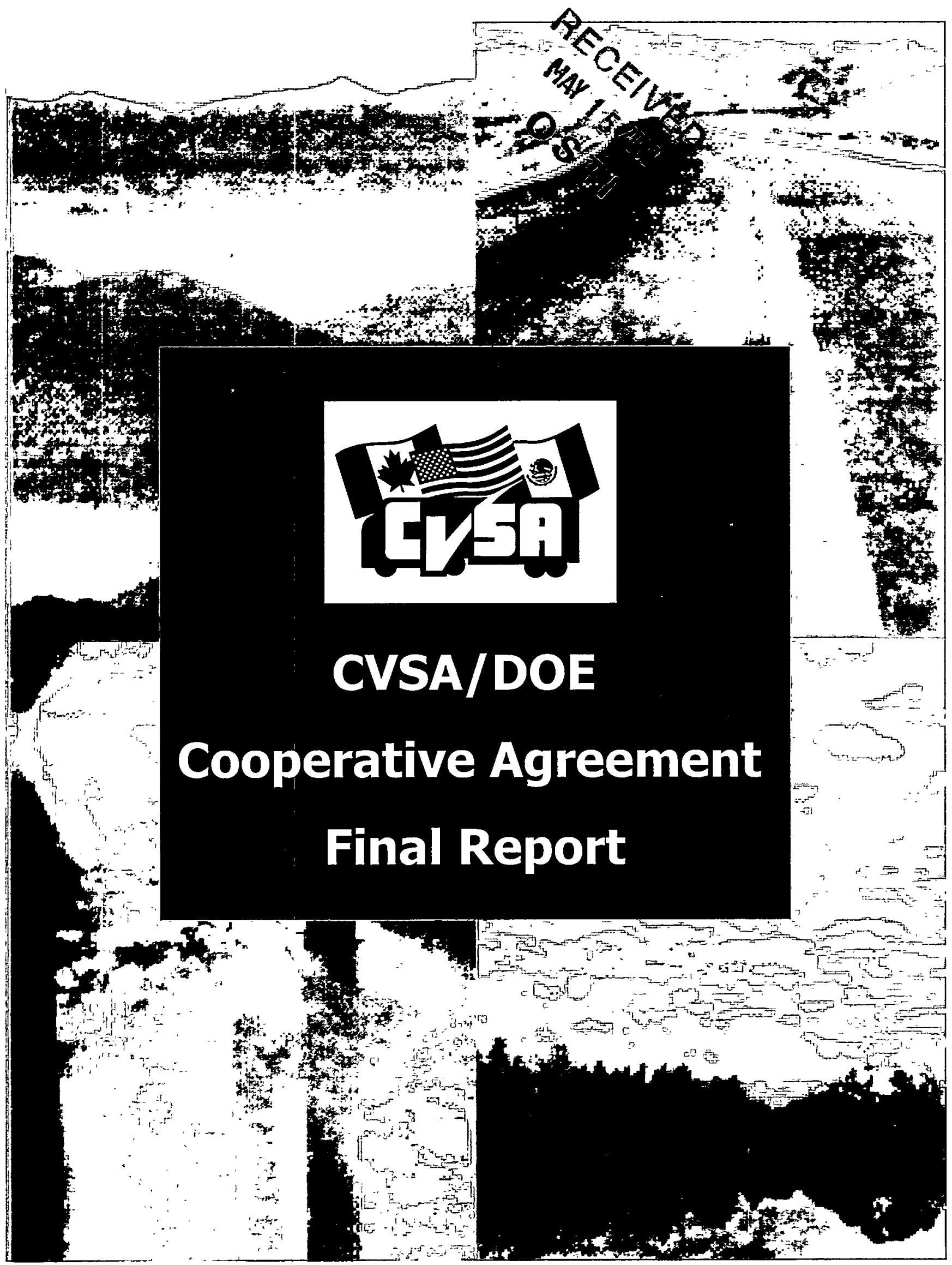




\section{DISCLAIMER}

This report was prepared as an account of work sponsored by an agency of the United States Government. Neither the United States Government nor any agency thereof, nor any of their employees, make any warranty, express or implied, or assumes any legal liability or responsibility for the accuracy, completeness, or usefulness of any information, apparatus, product, or process disclosed, or represents that its use would not infringe privately owned rights. Reference herein to any specific commercial product, process, or service by trade name, trademark, manufacturer, or otherwise does not necessarily constitute or imply its endorsement, recommendation, or favoring by the United States Government or any agency thereof. The views and opinions of authors expressed herein do not necessarily state or reflect those of the United States Government or any agency thereof. 


\section{DISCLAIMER}

\section{Portions of this document may be illegible in electronic image products. Images are produced from the best available original document.}




\title{
COMMERCIAL VEHICLE SAFETY ALLIANCE (CVSA) / DEPARTMENT OF ENERGY (DOE) COOPERATIVE AGREEMENT FINAL REPORT
}

\author{
Prepared by \\ Commercial Vehicle Safety Alliance
}

October 1999

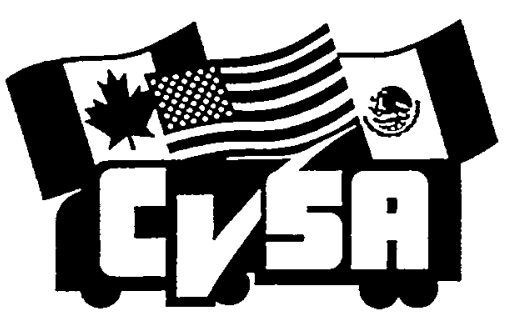


For information concerning this report and requests for Appendix items not included in this report distribution, contact:

Commercial Vehicle Safety Alliance

5430 Grosvenor Lane, Suite 130

Bethesda, MD 20814

Phone: (301) 564-1623

Fax: (301) 564-0588 


\section{EXECUTIVE SUMMARY}

This report provides a summary of the activities conducted since September 1986 under cooperative agreements between the Commercial Vehicle Safety Alliance (CVSA) and the U. S. Department of Energy (DOE). These activities include the development of the Enhanced North American Standard (ENAS) inspection procedures for inspecting drivers, equipment and cargo involved in the transportation of radioactive materials. The activities also include conducting a pilot study to evaluate the soundness of the procedures, develop training curricula, conduct training, perform inspections and generate evaluations to support recommendations. The following are the main conclusions and recommendations resulting from the work performed under the cooperative agreements.

- The set of ENAS inspection procedures and out-of-service criteria was developed for select radioactive motor carrier shipments by a wide range of federal, state and provincial government officials and inspectors, motor carrier industry representatives, national radiological experts, a research organization, and CVSA staff. It has proven to be a viable and necessary set of inspection criteria, which will go a long way to insure safe and efficient transportation of radioactive materials. It also has the potential of alleviating the popular perception that transportation of radioactive materials is inherently dangerous.

- The point of origin "defect free" by the ENAS inspection is a standard that is attainable and if followed closely will insure a relatively defect free vehicle at the point of destination. Random point of destination inspections are recommended to evaluate the inspection program including inspector training.

- Although the inspection data obtained in the pilot study are limited, it is the considered opinion of CVSA that there is generally no need for en route inspections, unless required by a jurisdiction's regulation. Furthermore it was found that jurisdictions will honor the enhanced decal and grant reciprocity thereby expediting shipments.

- The research design of the original cooperative agreement changed considerably over the years due to the delay in WIPP shipments, funding shortfalls and other factors beyond the control of CVSA. Several other shipments were then used with mixed results, with the most effective and exemplary being the Cesium Campaign and the limited number of WIPP shipments just prior to completing this final report. The original research design called for the collection of data such as weather factors, road conditions, and terrain characteristics that had to be eliminated in the final pilot study design.

- There is widespread support for the ENAS within the CVSA organization, which consists of all the fifty states, the Canadian provinces and Mexico. This was demonstrated by the overwhelming approval of all the ENAS proposals placed before the CVSA membership, as well as the large number of requests for the specialized inspector training. 
- In October 1997, the membership of CVSA adopted the ENAS for select DOE radioactive shipments. In July 1999, with the results of the pilot study and encouragement of DOE, the CVSA membership adopted the ENAS for all highway route controlled quantities of radioactive materials and transuranic waste.

- The Outreach Program with the theme "Safety and Efficiency in the Transportation of Radioactive Materials" has proven to be a valuable tool in projecting the importance of the ENAS program and demonstrating what is being done to insure safe transportation of radioactive materials. The RAD Inspection News newsletter is a vital and important link to the inspectors and provides critical information to assist them in completing their responsibilities.

- The three day basic inspector training course has been revised over the years and now reflects a training course which is highly evaluated, cost effective, and sought after by a number of states.

- The industry inspection awareness training, as provided by CVSA, was instrumental in providing drivers who were familiar with the ENAS inspection and generally eliminated any problems prior to the ENAS inspection. This occurred during the Cesium Campaign and WIPP shipments, with both shipping campaigns being viewed as exemplary. These shipments also used dedicated drivers that greatly assisted in the shipments receiving their high ratings.

- The inspector refresher course requirement is necessary to maintain a credible, uniform and viable program. This needs to be maintained and monitored by CVSA to insure that the inspector requirements are met and inspection procedures are followed. 


\section{Table of Contents}

Executive Summary ............................................................................................................ii

Abbreviations and Acronyms ........................................................................................ vii

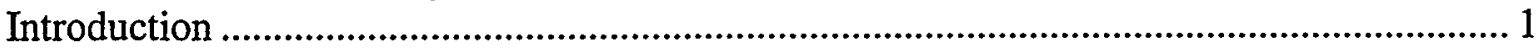

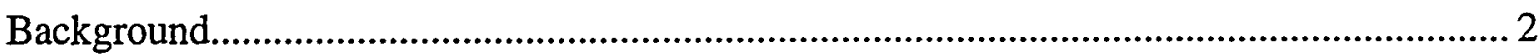

The Commercial Vehicle Safety Alliance ........................................................................ 2

The Cooperative Agreement.................................................................................... 3

Summary of Activities..................................................................................................

Program Planning and Design .....................................................................................

Product Development ...................................................................................................

Pilot Program Data Collection and Results ................................................................. 13

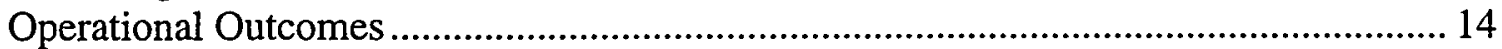

Future of Enhanced Inspection Program .................................................................. 17

Federal Law Requirements...................................................................................... 17

Nuclear Waste Policy Act (NWPA) ............................................................................ 18

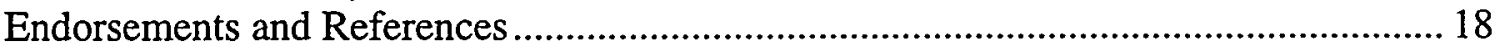

CVSA Adoption of ENAS Inspection Program ............................................................ 18

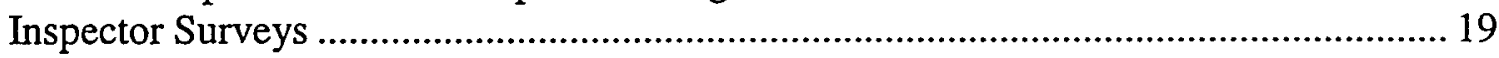

Training Curriculum ............................................................................................. 19

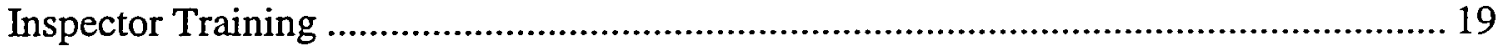

Data Collection

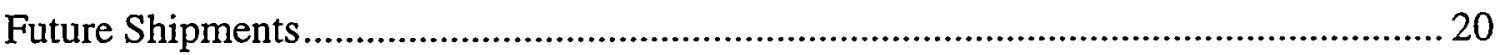

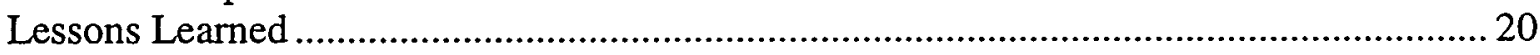

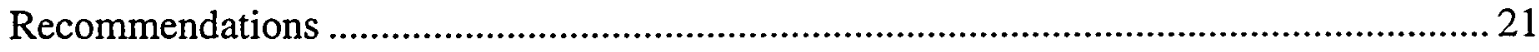

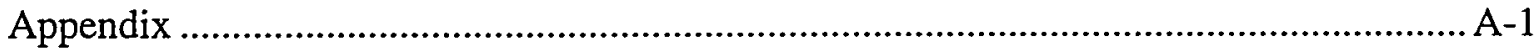




\section{List of Tables}

Table 1. Period of Performance and Amount Awarded for the Cooperative Agreements between DOE and CVSA ……………..............................................................

Table 2. CVSA Enhanced North American Standard Training Course Agenda.................. 9

Table 3. Summary of Enhanced North American Uniform Inspector Training Classes.... 11

Table 4. Summary of Current Enhanced Inspectors by State

\section{List of Figures}

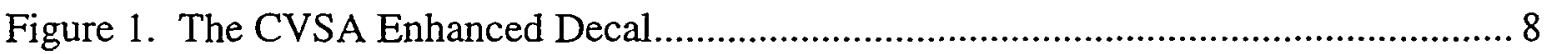

Figure 2. Content of the Training Program Student Manual.............................................. 10

Figure 3. The Outreach Program Display Unit ............................................................... 13 


\section{ABBREVIATIONS AND ACRONYMS}

$\begin{array}{ll}\text { CFR } & \text { Code of Federal Regulations } \\ \text { COHMED } & \text { Cooperative Hazardous Materials Enforcement Development } \\ \text { CRCPD } & \text { Conference of Radiation Control Program Directors, Inc. } \\ \text { CVSA } & \text { Commercial Vehicle Safety Alliance } \\ \text { DOE } & \text { Department of Energy (U.S.) } \\ \text { DOT } & \text { Department of Transportation (U.S.) } \\ \text { EM } & \text { Office of Environmental Management (U.S. DOE) } \\ \text { ENAS } & \text { Enhanced North American Standard } \\ \text { FHWA } & \text { Federal Highway Administration (U.S. DOT) } \\ \text { FMCSR } & \text { Federal Motor Carrier Safety Regulations (U.S. DOT) } \\ \text { H.M. } & \text { Hazardous Materials } \\ \text { HAZMAT } & \text { Hazardous Materials } \\ \text { HMR } & \text { Hazardous Materials Regulations (HMR), 49 CFR, Parts 100-199 } \\ \text { HMTA } & \text { Hazardous Materials Transportation Act, 1974 } \\ \text { HRCQ } & \text { Highway Route Controlled Quantity (of Radioactive Material) } \\ \text { JTA } & \text { Job Task Analysis } \\ \text { MCSAP } & \text { Motor Carrier Safety Assistance Program (FHWA/U.S. DOT) } \\ \text { MOU } & \text { Memorandum of Understanding } \\ \text { NCAI } & \text { National Congress of American Indians } \\ \text { NA } & \text { North American } \\ \text { NAS } & \text { North American Standard } \\ \text { NRC } & \text { Nuclear Regulatory Commission (U.S.) } \\ \text { NTP } & \text { National Transportation Program } \\ \text { NWPA } & \text { Nuclear Waste Policy Act } \\ \text { OCRWM } & \text { Office of Civilian Radioactive Waste Management (U.S. DOE) } \\ \text { OHMT } & \text { Office of Hazardous Materials Transportation (RSPA/DOT) } \\ \text { RAM } & \text { Radioactive Materials } \\ \text { RQ } & \text { Reportable Quantity } \\ \text { SNF } & \text { Spent Nuclear Fuel } \\ \text { SSEB } & \text { Southern States Energy Board } \\ \text { TEC } & \text { Transportation External Coordination } \\ \text { TI } & \text { Transport Index } \\ \text { TRU } & \text { Transuranics } \\ \text { WGA } & \text { Western Governors' Association } \\ \text { WIPP } & \text { Waste Isolation Pilot Project } \\ & \end{array}$




\section{COMMERCIAL VEHICLE SAFETY ALLIANCE (CVSA) / DEPARTMENT OF ENERGY (DOE) COOPERATIVE AGREEMENT FINAL REPORT}

\section{INTRODUCTION}

This report provides a summary of the activities conducted since September 1986 under cooperative agreements between the Commercial Vehicle Safety Alliance (CVSA) and the U. S. Department of Energy (DOE). These activities include the development of enhanced procedures for inspecting drivers, equipment and cargo involved in the transportation of radioactive materials. These procedures are known as the Enhanced North American Standard (ENAS) inspection procedures. The activities also include conducting a pilot study to evaluate the soundness of the procedures, develop training curricula, conduct training, perform inspections and generate evaluations to support recommendations.

The Background section of this report provides an overview of CVSA and the cooperative agreements. The Summary of Activities section describes the activities and accomplishments under the cooperative agreements in the areas of program planning and design, product development, pilot program data collection and analysis, and operational outcomes. The last three sections of the report discuss the future of the enhanced inspection program, and provide lessons learned from the enhanced inspection program and recommendations for the continuity and acceptance of the program. The Appendix contains documents produced under the cooperative agreements. These documents are referenced in the report as numbers enclosed in brackets (e.g., $[1,2,3]$ ) that correspond to the item numbers listed in the contents table of the Appendix 1 .

Over the thirteen years of the cooperative agreements, there have been several adjustments to or in some cases elimination of objectives as originally proposed. These were a result of a lack of shipments, funding shortfalls, and other factors beyond the control of CVSA. Despite the changes that were necessary, several assumptions or perceptions were developed by CVSA. These are:

- the public perceives radioactivity and radioactive materials as inherently dangerous and believes there should be no exposure to the public, unless used in medical procedures;

- the public perceives transporting radioactive materials as generally dangerous and would rather not be in the same vicinity of any transportation effort;

- the public perceives that transporting radioactive materials, if it must be done, must be done in an overly cautious and safe manner;

\footnotetext{
${ }^{1}$ Due to the large size of the items in the Appendix, only the first item in the Appendix [1], Summary Report on CVSA/DOE Pilot Study Data Collection Results, is included in the general distribution of this report. Requests for copies of the other Appendix items may be made to CVSA Headquarters, 5430 Grosvenor Lane, Suite 130, Bethesda, MD 20814, (301) 564-1623.
} 
- the public demands that radioactive materials shipments be checked and rechecked -they have built a viable trust factor in state and local personnel to oversee the safe transportation of radioactive material;

- the public perception of risks associated with the transportation of radioactive materials will have an impact on the future of the enhanced inspection program;

- the U. S. Department of Transportation (DOT) is charged by Federal statute to conduct inspections on select radioactive shipments prior to movement of the material and the ENAS inspection procedures meet this requirement;

- the DOE maintains a strong position that radioactive materials, especially their shipments, be handled and transported in as safe and efficient manner as possible;

- the DOT maintains a strong position that radioactive materials be handled and transported according to Federal regulations and expedited as safely and efficiently as possible;

- the radioactive materials Federal shipping requirements already exceed those for general merchandise;

- the CVSA maintains a strong position that shipments containing radioactive materials must be transported in a safe and efficient manner taking into consideration the public perception of radioactive materials;

- the enforcement community generally will expedite and support shipments of radioactive materials if it is shown and demonstrated that the shipments exceed the safety requirements as set for a general merchandise carrier;

- once trained and made aware of the requirements of the ENAS the enforcement community generally will, with only a few exceptions due to state laws, give reciprocity to another jurisdiction's ENAS inspections;

- the enhanced program will generally be followed across the United States resulting in uniformity and reciprocity in the transportation of spent nuclear fuel, high level radioactive waste, and transuranics (TRU); and

- the benefits of trained safety inspectors following uniform stringent standards across the country will be realized by the public in terms of education, trust, and assurance that radioactive materials are transported in as safe a manner as humanly possible.

\section{BACKGROUND}

\section{The Commercial Vehicle Safety Alliance}

The Commercial Vehicle Safety Alliance (CVSA) is a non-profit organization of federal, state, and provincial government agencies and representatives from private industry in the United States, Canada and Mexico dedicated to improving commercial vehicle safety. The Alliance serves as the major focal point for bringing together state/provincial officials with truck/bus industry interest and federal governments in a unique discussion and problem solving interchange. 
The CVSA began informally as a group of western state and provincial agencies that had the responsibility for conducting commercial vehicle enforcement activities. The first meeting of the founding organization was held in 1980. The meeting highlighted areas of common need and discussed ways in which uniform standards, procedures, and methods could be utilized to the greatest effectiveness. The CVSA then developed the Critical Item Truck and Bus Inspection Procedure which focused inspection efforts on vehicle equipment, cargo and driver conditions that are most often identified as causing or contributing to accidents. The procedure is currently known as the North American Standard Inspection Procedure. An important component of this procedure is to affix to an inspected vehicle a CVSA decal that indicates that the vehicle has passed the North American Standard Inspection.

The CVSA has attained its international leadership in safety enhancement of the commercial motor vehicle industry by providing a basic operating environment to achieve uniformity, compatibility, and reciprocity of inspections and motor carrier safety enforcement activities for its member jurisdictions. The CVSA serves as a focal point for bringing together state, federal government, and provincial officials, along with the truck and bus industry interests, in a one-of-a-kind discussion and problem solving interchange. The CVSA's objectives are to enhance the safety of commercial vehicles, improve commercial vehicle operation, minimize schedule delays, ensure effective allocation of resources, and promote reciprocity of inspections to avoid duplication of effort.

Currently, CVSA is comprised of all 50 states, two U.S. territories, twelve Canadian provinces and territories and Mexico. The member agencies include state police, highway patrols, public service and utility commissions, departments of transportation, motor vehicle and public safety departments, Canadian provincial governments, the Mexican government and supporting groups such as the U.S. Department of Transportation (DOT), the DOE, Canadian Transport Officials and over 200 associate industry members. Members, who represent the lead enforcement agency in each state, province or country, sign a Memorandum of Understanding (MOU) and recognize and agree to uniform inspection standards and procedures as developed by CVSA. A copy of the MOU is included in the Appendix [34]. One of the significant elements of the MOU is a reciprocity agreement to honor inspections conducted by member agencies that are authorized to affix the CVSA decal. The CVSA organizational structure provides the framework for commercial vehicle uniformity and reciprocity in the U.S., Canada, and Mexico. It also establishes a system in which associate members can participate and contribute to the safety effectiveness of CVSA.

\section{The Cooperative Agreement}

With the advent of nuclear power more than forty years ago, high level radioactive waste began accumulating in this country. Congress, in recognizing that a disposal policy had to be established, passed the Nuclear Waste Policy Act of 1982. This act designated that the DOE Office of Civilian Radioactive Waste Management (OCRWM) has the responsibility of implementing a waste management system, including the transportation of the waste and construction of a repository. 
In 1986 OCRWM recognized CVSA as the organization of state officials responsible for the administration and enforcement of motor carrier safety laws. The OCRWM requested that CVSA enter into a cooperative agreement to develop uniform inspection standards that would comply with all pertinent federal regulations governing motor carrier safety and the transportation of radioactive materials. In November 1987, CVSA presented OCRWM with a draft inspection standard recommending a uniform inspection procedure for drivers, equipment and the cargo. This draft standard became known as the Enhanced North American Standard Inspection for Transportation of Radioactive Materials. Vehicles passing this rigid inspection are identified with a special CVSA radioactive inspection decal.

The OCRWM extended the cooperative agreement with CVSA to conduct a pilot study to evaluate the soundness of the procedures, develop training curricula, conduct training, perform inspections and generate statistical evaluations that could support determinations about how often trucks should be inspected and which mechanical or driver items contributed to out-of-service findings. From these data, DOE hoped to identify operational or programmatic practices that would contribute to even greater levels of safety in these kinds of shipments while maintaining reasonable operating requirements. The original projected transportation campaign to be used in the Pilot Study was the Waste Isolation Pilot Plant (WIPP) shipments transporting radioactive waste into a repository at Carlsbad, New Mexico. These shipments were delayed, however, and without a fixed shipping date, the attention of the Pilot Study turned to other DOE radioactive shipments.

The initial cooperative agreement was between CVSA and OCRWM and it began in September 1986. It was renewed in July 1994 and ended on June 30, 1999. Additional funds for training to support a non-WIPP transportation campaign were provided from the DOE Office of Environmental Management (EM) National Transportation Program (NTP) in 1995. After OCRWM's budget reductions in 1996, the EM NTP and WIPP program offices provided the additional funding needed to maintain the Pilot Study. The NTP and WIPP, which receive separate congressional mandated funds, elected to band together in one cooperative agreement with CVSA, which is administered by NTP. This cooperative agreement between CVSA and NTP continues until September 30, 2002. As of December 31,1998 the total amount awarded for all the cooperative agreements has been approximately $\$ 2,151,000$. Table 1 provides details on the period of performance and monetary award amount for each of the cooperative agreements. Copies of the CVSA proposals for the cooperative agreements are in the Appendix [2, 3, 4, 5, and 6]. 
Table 1. Period of Performance and Amount Awarded for the Cooperative Agreements between DOE and CVSA
DOE Office of Civilian Radioactive Waste Management
Project Number
Project Period
DE-FC01-86CH-10305
09/29/86 - 06/30/94
DE-FC01-94RW-00295
$07 / 01 / 94-06 / 30 / 99$

Amount Awarded

$\$ 1,045,797$

$\$ 810,258$

DOE Environmental Management NTP and the Waste Isolation Pilot Plant

Project Number

Project Period

Amount Awarded

DE-FC04-97AL78356

10/01/97 - 09/30/00

$\$ 270,000$

NTP Training Funds

$04 / 26 / 95-09 / 30 / 95$

Total Department of Energy Funding Awarded through 12/31/98

$\$ 2,151,055$

Note: Funding documents are available at the Commercial Vehicle Safety Alliance Headquarters at 5430 Grosvenor Lane, Suite 130, Bethesda, MD 20814.

\section{SUMMARY OF ACTIVITIES}

\section{Program Planning and Design}

Management Plan: In 1990 a management plan was prepared for the Pilot Study. A copy of this document is in the Appendix [7]. It describes the Pilot Study's technical tasks and schedules; the management structure; and the roles and responsibilities of the various participants including the CVSA staff, CVSA committees, DOE components, participating states, state organizations and the Peer Review Panel. Key goals of the study were to evaluate the soundness of the draft inspection procedures, develop training curricula and generate significant statistical data that could support recommendations included in the procedures.

CVSA Pilot Study Committees: Initially four committees, Research Design, Inspection, Training, and Data Analysis, were established to conduct the major elements of the Pilot Study. Descriptions of these committees can be found in the Management Plan [7]. These committees were responsible for planning and designing the initial products for the Pilot Study in each of their respective areas. Over time and as their initial tasks were completed, these committees evolved into the RAM Subcommittee of the Standing CVSA Hazardous Materials (HAZMAT) Committee which currently meets annually to review program status, discuss and resolve issues, and plan future activities. Copies of the Subcommittee's meeting minutes are in the Appendix [9].

Peer Review Panel: A peer review panel was established for ensuring the quality, focus and credibility of the initial Pilot Study products such as the literature review, research 
design, training curriculum, and inspection form. Panel members were from the transportation industry, federal and state agencies, utilities, and academia. The panel ensured technical accuracy of the work as well as provided input to the Pilot Study planning and design activities.

Literature Review: A literature review was conducted and the results documented in a report in February 1991. A copy of the report is in the Appendix [8]. The report presents information gathered and analyzed in support of DOE's and CVSA's efforts to develop and implement inspection procedures for commercial vehicles transporting radioactive materials in accordance with the Nuclear Waste Policy Act. This information was used by DOE and CVSA to support the design of the Pilot Study to evaluate the draft inspection materials; establish procedures for pre-shipment inspections and assess the need for subsequent inspections while the vehicles are in transit; and develop training materials to facilitate adoption and implementation of the final CVSA inspection procedures in a manner acceptable to the states and the public. To assist in developing the Pilot Study, the literature review was conducted to identify commercial vehicle safety issues. The report addresses institutional, vehicle, driver, and environmental factors identified in the literature as inspection program concerns; discusses these factors in relation to the CVSA Pilot Study objectives; provides recommendations; and highlights areas where further research is needed.

Research Design: The research design document, a product of the Research Design Committee, was completed in July 1991. A copy of the document is included in the Appendix [10]. The research design lays out the overall scheme of the research activities for the Pilot Study, presents the conceptual and theoretical framework guiding the research, and describes the methods to be used to gather and analyze the data. The research design document includes a statement of objectives of the research, the subject of the research, and the statistical research hypotheses to be tested. It includes a summary of assumptions about resource availability and constraints, a summary of the variables and their measurement, and a description of the shipment sample, sampling procedures, and data quality assurance procedures. Also included in the document is a description of the data reduction, verification, management and analysis procedures to be used.

The original research design was based on a minimum of $150-200$ similar-type shipments for statistical analysis. When it became apparent that the WIPP shipments would be delayed the issue of reduced sample size, as well as other research design issues were examined. A paper describing these issues and alternative approaches was written in May 1994. A copy of this paper is included in the Appendix [11]. Subsequently by the end of March 1995 the research design document had been revised, reissued, and renamed the "Plan for the CVSA-DOE Pilot Inspection Study". A copy of this plan is included in the Appendix [12]. This current plan describes a modified study design that builds upon prior achievements and focuses on demonstration and validation of the components of an effective inspection program. Specifically there are five major objectives of the study under this plan: 
- validate and gain acceptance of the ENAS inspection procedures,

- demonstrate the ability to conduct ENAS inspections and ensure compliance,

- determine the effectiveness of the point of origin "defect-free" policy,

- validate the quality of the program components, and

- document the conditions of the shipments and inspections.

Other Program Planning and Design Activities: A Data Requirements and Analysis Strategy paper was developed in March 1991. It provides a framework for determining the measures, analyses and applications needed to achieve the goals of the Pilot Study. A copy of this document is in the Appendix [13]. In March 1993 data validation procedures were proposed for data collection and data entry activities. These procedures cover the areas of vehicle inspections, point of destination driver interviews, secondary data (e.g., highway characteristics, road and weather conditions, institutional procedures, etc.), data entry and data management. A copy of these procedures is in the Appendix [14]. A research report on alternative methods for characterizing highway routes was completed in January 1994. This report presents the results of an assessment of alternatives to compile a database that characterizes the key attributes of routes that would be used for the Pilot Study shipments. A copy of this report is in the Appendix [15]. These three documents were based on the assumption that the data would be primarily collected from the WIPP shipments. Due to the delay in the WIPP shipments, many of the procedures and methods described in these documents were not used.

\section{Product Development}

ENAS Inspection Procedures and Out-of-Service Criteria: The ENAS inspection includes more stringent criteria than the NAS inspection for placing a vehicle out-ofservice and has additional inspection and out-of-service criteria items than the NAS inspection. The draft enhanced inspection procedures were first issued in November 1987. The Inspection Committee was responsible for revising the enhanced procedures for the Pilot Study. They were first issued in the "flipchart" format in 1993. At least annually since then the flipchart has been revised to incorporate NAS and regulation changes and distributed to enhanced inspectors. A major format change was made in 1998 in which the NAS and ENAS out-of-service criteria are displayed side-by-side in the flipchart. The current version of the flipchart is dated April 1, 1999 and is titled "CVSA North American Standard Out-of-Service Criteria and Enhanced North American Standard Inspection Procedures and Out-of-Service Criteria for Commercial Highway Vehicles Transporting Transuranics, Spent Nuclear Fuel, and High-Level Radioactive Waste". A copy of this document is in the Appendix [16].

CVSA Enhanced Decal: This decal was developed by CVSA. It is affixed to a vehicle passing all the requirements of the ENAS inspection procedures at the point of origin. This decal is valid for the one trip and it is removed at the point of destination unless en route the vehicle is placed out-of-service according to the ENAS criteria. In this case the decal is removed and once the violations corrected, the vehicle is re-inspected and a new enhanced decal affixed if the vehicle passes the ENAS inspection. Inspections at the 
points of origin and destination were vital for the Pilot Study. During the Pilot Study, states en route were able to elect to honor the decal and not inspect the unit or they may conduct a complete enhanced inspection of the unit, driver, and cargo. The current version of the decal is shown in Figure 1. As of September 1999 when the CVSA membership approved the definition of a Level VI (ENAS) Inspection as part of CVSA operational policy (see below on Future of Enhanced Inspection Program - CVSA Adoption of ENAS Inspection Program), destination inspections may be conducted on a "spot check" basis for all high level radioactive materials and transuranic waste.

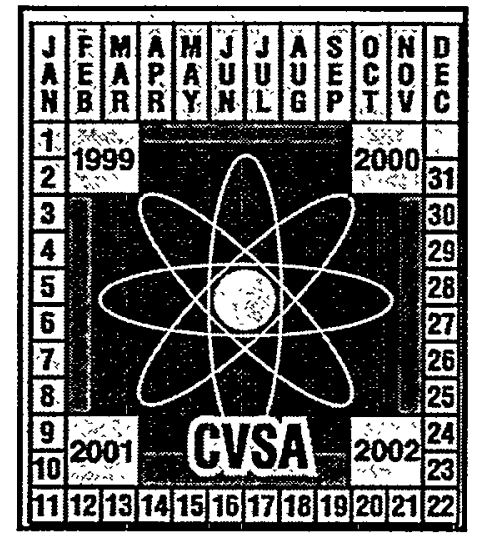

Figure 1. The CVSA Enhanced Decal

Data Collection Forms: The Data Analysis Committee was responsible for developing the data collection forms for the Pilot Study. Two forms have been used to collect data for the Pilot Study. The CVSA/DOE Spent Fuel/Transuranic/High Level Radioactive Waste Pilot Study Inspection Form is used to record the enhanced inspection data. It was first printed in December 1991 and was revised in April 1995. A copy of the current form and the instructions for completing the form are in the Appendix [17]. The Point of Destination Driver Interview Form was used to collect data from the drivers of the vehicle on the inspections, events, and problems encountered during the trip. It was given to the drivers by the enhanced inspector at the point of origin. This form was initially printed in January 1992. A copy of the current version of the form and the instructions for distributing the form are in the Appendix [18].

Inspector Training Curriculum: The Training Committee was responsible for developing the initial enhanced inspector basic training curriculum. In August 1992, the first training course was conducted. Since then the basic elements of the training curriculum have remained relatively stable, while the training materials have been updated and improved several times in response to lessons learned from the classes conducted. Table 2 is the current course agenda and Figure 2 is the contents page from the current student manual. 
Table 2. CVSA Enhanced North American Standard Training Course Agenda

\begin{tabular}{|l|l|l|l|l|l|}
\hline & Monday & Tuesday & Wednesday & Thursday & Friday \\
\hline $8: 00 \mathrm{am}$ - Noon & Travel Day & $\begin{array}{l}\text { Introduction to } \\
\text { Radiation \& } \\
\text { Radioactivity }\end{array}$ & $\begin{array}{l}\text { Inspection Form } \\
\text { Write-up } \\
\text { Instrumentation } \\
\text { \& Survey } \\
\text { Procedures } \\
\text { Inspection } \\
\text { Demonstration } \\
\text { Feview Final } \\
\text { Exam } \\
\text { Course } \\
\text { Evaluation }\end{array}$ & Travel Day \\
& $\begin{array}{l}\text { Practical } \\
\text { Exercises } \\
\text { Work Projects }\end{array}$ & LunCH & Travel Day & \\
\hline Noon-1:00 pm & $\begin{array}{l}\text { LUNCH } \\
\text { Introduction } \\
\text { Enhanced } \\
\text { North } \\
\text { American } \\
\text { Standard } \\
\text { Levell } \\
\text { Inspection } \\
\text { Procedures }\end{array}$ & $\begin{array}{l}\text { Radioactive } \\
\text { Regulations }\end{array}$ & $\begin{array}{l}\text { Practical } \\
\text { Exercises } \\
\text { Work Projects }\end{array}$ & & \\
\hline
\end{tabular}




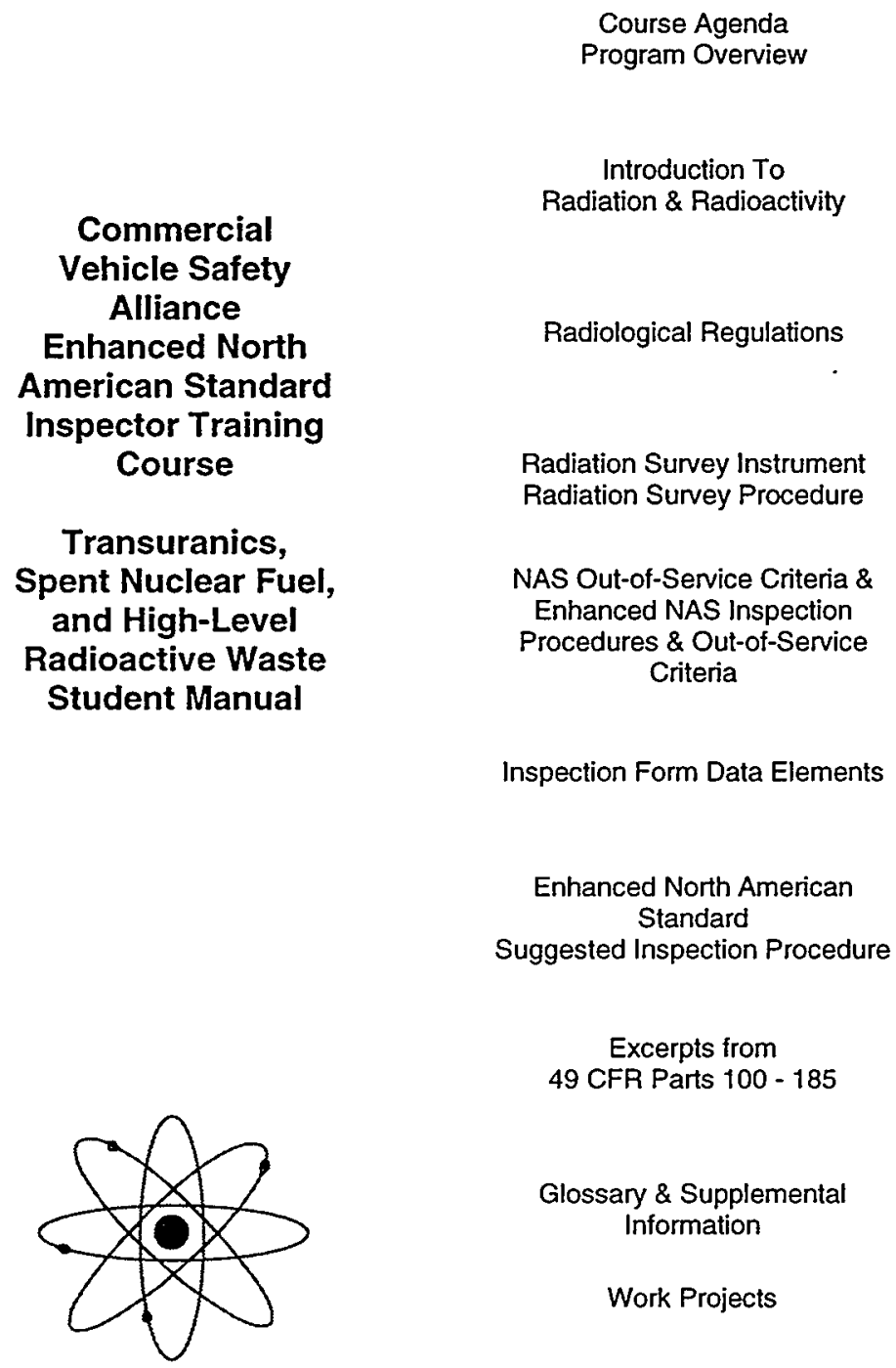

October 1999

\section{Figure 2. Content of the Training Program Student Manual}

Basic Enhanced Inspector Training Classes: The Oregon Public Utility Commission initially conducted the basic enhanced inspector training classes under a cooperative agreement with CVSA. After July 1995 the classes were conducted using part-time CVSA staff and selected instructors from state and federal motor carrier enforcement agencies. This approach provided more flexibility in scheduling and was a more cost-effective method. Both inspectors and industry representatives have attended the classes. Inspectors are certified as enhanced inspectors if they receive a passing score on the final exam. The first class was held in August 1992. To date there have been 31 classes with a total of 529 attendees and 457 inspectors certified. Table 3 gives the number of attendees and inspectors certified for each class. 
Table 3. Summary of Enhanced North American Uniform Inspector Training Classes

\begin{tabular}{|c|c|c|c|c|c|}
\hline $\begin{array}{l}\text { Class } \\
\text { Noo }\end{array}$ & 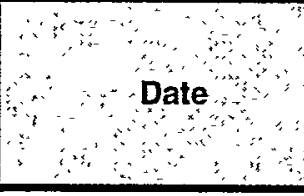 & Location & $\begin{array}{l}\text { Total } \\
\text { Number } \\
\text { of } \\
\text { Attendees }\end{array}$ & $\begin{array}{c}\text { Number of } \\
\text { Attendees } \\
\text { fom Industry } \\
\text { and Other } \\
\text { Government }\end{array}$ & $\begin{array}{l}\text { Number of } \\
\text { Inspectors } \\
\text { Gertified }\end{array}$ \\
\hline 1 & August 1992 & Woodburn, OR & 12 & & 12 \\
\hline 2 & February 1993 & Woodburn, OR & 12 & & 12 \\
\hline 3 & February 1994 & Denver, CO & 17 & 2 & 15 \\
\hline 4 & May 1994 & Shelton, WA & 20 & & 16 \\
\hline 5 & March 1995 & Clackamas, OR & 16 & 2 & $12^{*}$ \\
\hline 6 & May 1995 & Pikesville, MD & 14 & & 11 \\
\hline 7 & June 1995 & Richmond, VA & 18 & 1 & 17 \\
\hline 8 & August 1995 & Columbus, $\mathrm{OH}$ & 17 & 5 & 12 \\
\hline 9 & November 1996 & Henderson, CO & 14 & 5 & 8 \\
\hline 10 & March 1997 & Columbia, SC & 14 & 3 & 13 \\
\hline 11 & June 1997 & Lansing, MI & 15 & 2 & 13 \\
\hline 12 & August 1997 & Albuquerque, NM & 15 & $i$ & $9^{* *}$ \\
\hline 13 & September 1997 & Nashville, TN & $17^{* \pm *}$ & - - & 14 \\
\hline 14 & October 1997 & Las Vegas, NV & 14 & & 14 \\
\hline 15 & November 1997 & Reno, NV & 17 & . & 13 \\
\hline 16 & November 1997 & Springfield, IL & 18 & & 18 \\
\hline 17 & December 1997 & Elko, NV & 13 & & 12 \\
\hline 18 & January 1998 & Forsyth, GA & 12 & & 10 \\
\hline 19 & March 1998 & Tyler, TX & 13 & 1 & 11 \\
\hline 20 & April 1998 & Springfield, IL & 30 & & 30 \\
\hline 21 & June 1998 & Denver, CO & 16 & 2 & 13 \\
\hline 22 & July 1998 & Garland, TX & 12 & is & 10 \\
\hline 23 & July 1998 & Woodburn, OR & 17 & & 17 \\
\hline 24 & August 1998 & West Sacramento, CA & 27 & & 27 \\
\hline 25 & October 1998 & Jackson, MS & 20 & : & 17 \\
\hline 26 & November 1998 & Midland, TX & 27 & & 26 \\
\hline 27 & March 1999 & Sacramento, CA & 23 & & 22 \\
\hline 28 & May 1999 & Harrisburg, PA & 18 & 4 & 13 \\
\hline 29 & June 1999 & Lincoln, NE & 20 & & 20 \\
\hline 30 & August 1999 & Albuquerque, NM & 19 & 3 & 9 \\
\hline 31 & August 1999 & Phoenix, AZ & 12 & 1 & 11 \\
\hline Total & & & 529 & 28 & 457 \\
\hline
\end{tabular}


Outreach Program: The theme of the Outreach Program developed under the cooperative agreement between OCRWM and CVSA is "Safety and Efficiency in the Transportation of Radioactive Materials". The objective of this outreach program is to convey to stakeholders and others the goals and objectives of the Cooperative Agreement as well as the results of the Pilot Study. The elements of the Outreach Program include brochures, videotapes, a display unit for conferences/trade shows, and speakers, and a quarterly newsletter. The display unit is shown in Figure 3. It depicts the various efforts that go into training a motor carrier inspector to conduct enhanced inspections of radioactive shipments. Program speakers have made presentations before nationally recognized organizations, state conferences and meetings, private agencies, law enforcement officials, and general citizen groups. The quarterly newsletter, $R A D$ Inspection News, was first published in November 1994. It has a circulation of 797, including 415 currently certified enhanced inspectors. The newsletter keeps the certified enhanced inspectors and others current on what is occurring within the Cooperative Agreement and is also a training tool for the inspectors. It includes summaries of programrelated activities, concerns and issues as well as related DOT interpretations. Copies of the back issues of the newsletter are in the Appendix [19]. Examples of other Outreach Program elements are in the Appendix [20,21, 22 and 23]. The Outreach Program also includes program participation in transportation-related initiatives and committees. These groups and roles include:

- Transportation External Coordination (TEC) Working Group -- member representing CVSA,

- Western Governors' Association (WGA) -- advisor,

- Southern States Energy Board (SSEB) -- advisor,

- Midwestern Council of State Government -- advisor,

- National Congress of American Indians (NCAI) -- advisor, and

- various CVSA committees -- member. 


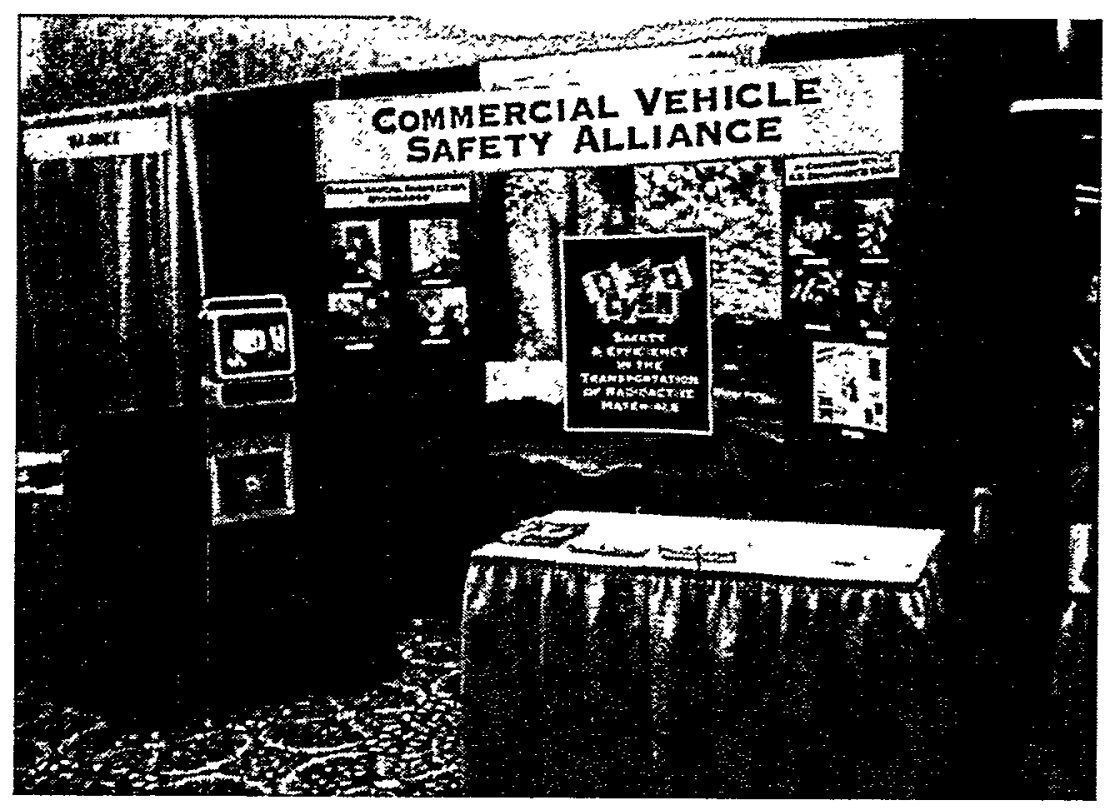

Figure 3. The Outreach Program Display Unit

\section{Pilot Program Data Collection and Results}

The original design of the Pilot Study called for detailed data collection activities and complex analyses based on the characteristics of the WIPP shipments. Because of the delay in the WIPP shipments and the desire to collect inspection data, other DOE radioactive shipments were identified that could be used for enhanced inspections that would utilize the inspection and driver interview forms. To date, three transportation campaigns have been used for data collection. Other sources of data include ongoing transportation campaigns and enhanced inspections conducted by the states on select shipments.

The Pilot Study Inspection Form and the Point of Destination Driver Interview Form have been the primary data collection tools. On occasion, surveys and interviews with inspectors and drivers have also been conducted. The follow subsections describe these data collection and analysis activities.

Cesium Campaign: This campaign began with 20 shipments of cesium capsules from the IOTECH facility in Northglenn, Colorado to the Hanford site in Washington State. These shipments were conducted over the course of one year beginning in May 1994. Enhanced inspections were conducted at the point of origin, the point of destination and at locations en route during each shipment. Data were collected on the inspections using inspection forms and driver interview forms. Utilizing surveys and interviews with inspectors and drivers, data were collected on various components of the inspection process such as training, conduct of inspections, and attitudes regarding enhanced inspections. A report was prepared in September 1995 on this part of the campaign and it is included in the Appendix [24]. Two final shipments of cesium capsules from 
Lynchburg, Virginia to Hanford were conducted in 1996 and the inspection results for these shipments were documented in the October 1996 issue of the RAD Inspection News which can be found in the Appendix [19].

LSAVNitric Acid Campaign: This campaign consisted of 25 paired shipments (total of 50) of Low Specific Activity (LSA)/nitric acid from Hanford, Washington to Portsmouth, Virginia. From Portsmouth, the LSA/nitric acid was then transported via ocean carrier to Great Britain for processing. The shipments were conducted from May through November 1995. Enhanced inspections were conducted at the point of origin, the point of destination and, on three occasions, en route during shipment. Data were collected on the inspections using inspection forms and driver interview forms. Utilizing surveys and interviews with inspectors and drivers, data were collected on various components of the inspection process such as training, conduct of inspections, and attitudes regarding enhanced inspections. A report was prepared in April 1996 on this campaign and it is included in the Appendix [25].

Other Campaigns/Inspections: Other campaigns and inspections in which data have been collected and summarized include the Brookhaven - Savannah River Campaign consisting of 25 shipments of spent nuclear fuel, the Oak Ridge - Savannah River Campaign consisting of monthly shipments of spent nuclear fuel, the initial WIPP shipments, and other various inspections conducted by the states. These data are reported both individually by campaign or group and together as a whole with the Cesium and LSANNitric Acid data in a summary report on the Pilot Study results. A copy of this report is in the Appendix [1].

\section{Operational Outcomes}

Several activities have been directed at improving the enhanced inspection program based on experience gained over the course of the Cooperative Agreement in conducting training, performing enhanced inspections, and collecting data.

Pilot Study Checklist: Based on experiences during the Cesium Transportation Campaign, a checklist was developed by the RAM Subcommittee of the Standing CVSA HAZMAT Committee and finalized in April 1996. This checklist delineates the roles and responsibilities of organizations involved in shipments included in the Pilot Study. These groups include CVSA, DOE Headquarters, on site DOE organizations, carriers, and state and tribal agencies. The checklist provides a method to help insure that the training, enhanced inspections and data collection are conducted without problems. A copy of the checklist is in the Appendix [26].

Job Task Analysis (JTA): In 1997 a job task analysis (JTA) for inspecting shipments of DOE radioactive materials was performed by the RAM Subcommittee of the Standing CVSA HAZMAT Committee in response to a request from the TEC Working Group. The JTA lists the tasks to be performed, the skills and knowledge that are required for the tasks and CVSA's recommendations for training and equipment needs to inspect DOE radioactive material shipments by motor carrier. The JTA was presented to the TEC 
Working Group and was accepted. The CVSA Executive Committee also adopted it. A copy of the JTA is in the Appendix [27].

Inspector Certification Acknowledgements: An inspector who receives the basic enhanced training and passes the course examination is certified by CVSA to conduct the ENAS procedures. Several items were developed under the Cooperative Agreement to signify this achievement, and include certificates, patches and pins. Certified inspectors receive these items to display or wear as appropriate and to show that they are CVSA certified enhanced inspectors.

Refresher Training and Re-certification of Inspectors: It is a CVSA requirement that certified enhanced inspectors attend refresher training at least once every two years to maintain their certification. To assist in meeting this requirement, CVSA conducted inspector refresher training in March 1995 at Las Vegas, in August 1996 at Denver, in May 1997 at Richland, Washington and in March 1998 at Columbus, Ohio. However, due to budget limitations and the increasing number of current certified inspectors ${ }^{2}$ around the country (see Table 4), it was decided to turn over the responsibility of refresher training to the states and to provide the states with the tools to conduct this training. The CVSA developed a train-the-trainer course that was held in June 1998 with representatives from 17 states attending. Trainers were then provided with copies of the training materials (e.g., student and instructor manuals, presentation viewgraphs, etc.) that had been developed especially for the refresher course. In addition, an automated system was established to provide the trainers with current information on the training status of the enhanced inspectors in their respective states.

\footnotetext{
${ }^{2}$ Current certified inspectors do not include those certified inspectors in the Table 3 total who have retired or otherwise left their inspector positions.
} 
Table 4. Summary of Current Enhanced Inspectors by State

\begin{tabular}{|c|c|}
\hline of & $\begin{array}{l}\text { Number of } \\
\text { Current certified } \\
\text { Inspectors }\end{array}$ \\
\hline Alabama & 2 \\
\hline Arizona & 10 \\
\hline California & 49 \\
\hline Colorado & 18 \\
\hline Georgia & 10 \\
\hline Idaho & 7 \\
\hline Illinois & 46 \\
\hline lowa & 5 \\
\hline Kentucky & 4 \\
\hline Louisiana & 4 \\
\hline Maryland & 4 \\
\hline Michigan & 10 \\
\hline Mississippi & 11 \\
\hline Nebraska & 6 \\
\hline Nevada & 38 \\
\hline New Jersey & 2 \\
\hline New Mexico & 27 \\
\hline New York & 1 \\
\hline Ohio & 14 \\
\hline Oregon & 14 \\
\hline Pennsylvania & 10 \\
\hline South Carolina & 16 \\
\hline Tennessee & 18 \\
\hline Texas & 45 \\
\hline Utah & 7 \\
\hline Virginia & 6 \\
\hline Washington & 24 \\
\hline Wyoming & 7 \\
\hline Total (28 states) & 415 \\
\hline
\end{tabular}

Industry Personnel Training: In response to the contractual requirements that drivers and maintenance personnel be trained in the NAS, hazardous materials and the enhanced inspection process for WIPP shipments, a course was developed by CVSA and approved by DOE for presentation to CAST employees and contract personnel who are involved with the WIPP shipments. The CVSA Executive Committee also approved this course. It was first conducted in March 1998 and more recently in July 1999. The course consists of 40 hours of classroom training and 40 hours of practical exercises. The CVSA designed course consists of all the elements of the NAS course (i.e., Level I and HAZMAT) except that the curriculum is modified to eliminate enforcement issues that do not apply to nonenforcement personnel. A copy of the course agenda is in the Appendix [28].

Drivers, mechanics, and other industry representatives regularly attend the basic enhanced training course along with state inspectors. Certificates of proficiency are awarded to those whom successfully complete the course and pass the final examination. 
Tribal Membership in CVSA: During the course of the Cooperative Agreement several meetings were conducted with various tribal leaders and normally in response to requests from the National Congress of American Indians (NCAI). These meetings were called to explain the CVSA inspection procedures and more specifically the ENAS inspection program for radioactive shipments. It was determined during these meetings that there were no provisions for tribal membership in CVSA. Since membership is critical to attaining uniformity and reciprocity of safety inspections, a position paper was developed in March 1996 and presented to the CVSA Executive Committee who unanimously approved membership for federally recognized tribes. A copy of this paper is in the Appendix [29]. To date there have been no tribal applications for CVSA membership, however it is anticipated that membership will occur when funds for tribal inspections are made available from DOE.

A tribal pilot inspection proposal was presented to DOE, in which was proposed selecting a group of tribal inspectors to conduct various levels of inspection including the complete ENAS inspection. A copy of this proposal is in the Appendix [30]. This proposal was denied due to funding shortfalls.

WIPP Transportation Interpretations: In response to confusion in the field concerning the transportation regulations for WIPP TRUPACT II containers (i.e., highway route controlled quantity [HRCQ] or not), CVSA published an interpretations paper developed by DOT in the July 1998 issue of RAD Inspection News and an updated version in the October 1999 issue of RAD Inspection News (both versions can be found in the Appendix [19]). The paper clarifies issues related to marking, labeling, and placarding, as well as issues related to the Uniform Waste Manifest and securement devices and front end structures on TRUPACT II containers.

Analysis of Enhanced Inspection Times: In August 1998, CVSA was requested to provide information on the time it takes to perform an enhanced inspection. This request came from a contractor developing the transportation protocols for future spent fuel shipments into the Yucca Mountain site in Nevada. Data from the Cesium Campaign were examined to prepare the estimate. From the Cesium Campaign there were a total of 85 inspections performed by six states in which complete information on the duration of the enhanced inspection was available. For these 85 inspections the average time to conduct the enhanced inspection was 56.5 minutes. Out of these 85 inspections, the minimum inspection time was 20 minutes and the maximum inspection time was 115 minutes.

\section{FUTURE OF ENHANCED INSPECTION PROGRAM}

\section{Federal Law Requirements}

Federal law (Section 16 of Public Law 101-615 dated November 16, 1990) dictates inspections of shipments of high level radioactive waste and nuclear spent fuel at the point of origin. The DOT has recognized their role in implementation of this law and CVSA, 
DOE and DOT have been working together to develop the ENAS procedures that can satisfy this requirement.

\section{Nuclear Waste Policy Act (NWPA)}

Under the NWPA, DOE is responsible for acceptance and transport of commercial spent nuclear fuel (SNF) from commercial utility sites to a federal facility for either storage or disposal. DOE has developed a draft RFP for the acquisition of commercial SNF acceptance and transportation services. In this draft RFP, the ENAS is included in the truck equipment design and operations requirements.

Under Section 180 (c) of the NWPA, DOE is required to provide technical assistance and funds to states and Indian tribes for training to cover procedures required for safe routine transportation of spent nuclear fuel or high-level radioactive waste. In a recent Federal Register notice of revised proposed policy and procedures on technical assistance and funding (63 FR 23753, April 30, 1998), OCRWM stated that one of its objectives is to provide funding and technical assistance for training for safety and enforcement inspections specific to NWPA truck shipments. The ENAS was specifically mentioned as an example of such inspections.

\section{Endorsements and References}

- The WGA has incorporated the ENAS in their WIPP Transportation Safety Program Implementation Guide. The WGA has also recommended that CVSA formally adopt the ENAS for shipments involving the transport of HRCQ radioactive materials and TRU waste. A copy of the letter stating the endorsement and recommendation is in the Appendix [31].

- The SSEB adopted the WGA WIPP Transportation Safety Program Implementation Guide and thereby endorses the ENAS.

- The CVSA enhanced decal is referenced in the booklet "A Reporter's Guide to the Waste Isolation Pilot Plant (WIPP)".

- The WIPP Transportation Plan contains detailed requirements for ENAS inspections and contract carrier personnel training.

- DOE protocols include a category "Inspections".

\section{CVSA Adoption of ENAS Inspection Program}

The RAM Subcommittee of the Standing CVSA HAZMAT Committee, appointed to monitor the enhanced inspection program during the course of the Cooperative Agreement, recommended that the CVSA general membership approved the ENAS inspection procedures and out-of-service criteria. A copy of the recommendation paper is in the Appendix [32]. In October 1997 the membership overwhelmingly endorsed the enhanced procedures and out-of-service criteria for approved DOE radioactive shipments.

In May 1999, the subcommittee recommended that the enhanced procedures and out-ofservice criteria be expanded to all highway route controlled quantities of radioactive 
materials (as defined by Title 49 CFR Section 173.403) and all transuranics. In conjunction with this recommendation a questionnaire was distributed to all known motor carriers within North America that transport HRCQ radioactive materials. The survey solicited the carriers' inputs and opinions regarding the use of the ENAS on all HRCQ shipments. The carriers responded that radioactive shipments should be held to a higher standard than general commodity shipments and they had very few concerns regarding the use of the ENAS on their shipments of HRCQ materials. The questionnaire and responses are included in the Appendix [33].

In July 1999, the CVSA membership, via a mail ballot, overwhelmingly approved the use of the ENAS on all HRCQ shipments of radioactive materials and transuranic waste. The procedures and out-of-service criteria are now known as the Level VI Inspection and are a part of the CVSA operational policies. A copy of the current CVSA operational policies is included in the Appendix [34].

\section{Inspector Surveys}

Certified enhanced inspectors periodically have been requested to provide feedback on various aspects of the enhanced inspection program. Such surveys occurred during the Cesium and LSA/Nitric Acid transportation campaigns and more recently in August 1996 during a refresher training class and again in December 1996 utilizing a mail-in format. The results of the mail-in survey were described in the April 1997 issue of the RAD Inspection News (which can be found in the Appendix [19]). The inspectors provide valuable information for the improvement and future direction of the enhanced inspection program. For example, inspectors have suggested that the ENAS should be included in the Appendix of the NAS (which has been done), that the format of the flipchart should be similar to the NAS (which has been done), and that the enhanced inspection procedures and out-of-service criteria should be used on HRCQ and TRU waste radioactive shipments (which is now adopted by CVSA).

\section{Training Curriculum}

The training curriculum will be maintained and updated as required.

\section{Inspector Training}

Various states have requested basic enhanced inspector training during the later part of 1999 and through mid 2000 . However the first priority will be to provide training to those states in which identified shipments originating, passing through, or arriving are imminent. Any training beyond this will be dependent on the funding available to provide training.

\section{Data Collection}

The CVSA Information Systems Committee is developing a supplement to the Motor Carrier Safety Assistance Program (MCSAP) SAFETYNET form (used to input NAS inspection data) that will incorporate the enhanced inspection data elements. A copy of the proposed form is in the Appendix [35]. 


\section{Future Shipments}

Future transportation campaigns that will have the ENAS inspection procedures applied to them are the WIPP shipments, the Foreign Research Spent Fuel shipments, and ongoing DOE and commercial HRCQ shipments.. The procedures will also be applied to high level radioactive waste, spent nuclear fuel, TRU, and other HRCQ shipments as approved by DOE in coordination with federal and commercial shippers.

\section{LESSONS LEARNED}

The following are lessons learned from the enhanced inspection program.

- Even though responsible carriers take pre-inspection actions to ensure their equipment meets the enhanced standards, state inspectors still have found violations.

- Refresher training for certified inspectors is critical to continuation of a viable and credible inspection program.

- In any given state, a designated, limited and select group of Hazardous Materials Specialists is more cost effective to the enhanced inspection program than training all enforcement personnel on the enhanced procedures.

- Steps must be taken to get a "buy-in" from shippers to include the enhanced inspection procedures in transportation plans. A strong commitment is necessary in providing a viable and efficient enhanced inspection program. This was evident during the Cesium and LSA/Nitric Acid shipping campaigns.

- The enhanced inspection program should only be used on select shipments; e.g., HRCQ shipments of radioactive material and special designated shipments such as WIPP. It should not be used on low level radioactive shipments such as the LSA/Nitric Acid shipments since the safety risk to the public is not as severe and there is a lack of commitment for including low level radioactive shipments under the ENAS.

- The law enforcement community became very supportive of the enhanced inspection program and welcomed this approach to inspecting radioactive shipments since in the past there has been general uncertainty and concern with inspecting radioactive shipments.

- During the point of origin inspection in certain states, the state radiological agency conducted their survey in conjunction with the law enforcement ENAS inspection. This cooperative effort expedited the inspections and enhanced the cooperation between the two state agencies.

- The prerequisite for attending the enhanced inspection training is certification in Level I and HAZMAT inspections. It was found that many inspectors attending the enhanced course did not have the expertise necessary for these two levels and they had great difficulty in using and understanding the basic DOT CFR-49 HAZMAT regulations.

- The Outreach Program developed on the enhanced inspection program has the potential for changing public perception on radioactive materials shipments. 
- It is necessary to review and revise the training and inspection materials to keep them current with changes in regulations and out-of-service criteria.

- Swipe tests for radioactive contamination on casks were initially conducted in some states. However it was decided that these tests were inappropriate for roadside inspections and would not become part of the ENAS inspection procedures.

- Deviations from tbe CVSA approved ENAS inspection procedures became evident during the Pilot Study with the conclusion drawn that more emphasis needs to be placed on inspectors following the approved procedures.

- A wide range of radiation survey instruments were found during the inspector training classes, with some devices being outdated and inaccurate.

- Personal radiation detection devices became an issue with no clear indication of which inspectors should receive the devices and when they should receive them. The resolution of this issue was left up to the individual jurisdictions.

\section{RECOMMENDATIONS}

As a result of the activities and accomplishments of the Cooperative Agreement, CVSA has approved and adopted the ENAS Inspection Procedure and Out-of-Service Criteria for all motor carrier shipments of $\mathrm{HRCQ}$ of radioactive materials and transuranic waste.

By adopting the enhanced procedure and out-of-service criteria, CVSA believes the enhanced inspection should be continued in order to insure the safe transportation of radioactive materials and alleviate the fears of the general public regarding radioactive materials transportation. The CVSA is committed to continue the enhanced inspection program, including the RAM subcommittee of the CVSA Hazardous Materials Committee that continually addresses issues related to the enhanced inspection program. This commitment is predicated upon receiving funding from sources outside of CVSA's normal functional operations. With respect to this commitment and the dependence of outside funding, CVSA provides the following recommendations to insure future continuity and acceptance of the enhanced inspection program. It is recommended that

- The DOT, Office of Motor Carriers and Highway Safety endorse and accept the ENAS procedures for all HRCQ shipments of radioactive material shipments as defined in 49 CFR Part 173.403 .

- The DOT, Office of Motor Carriers and Highway Safety continue to support the use of their personnel in the CVSA's ENAS inspector training in areas where they have the necessary expertise.

- The DOT and CVSA review the Level I and HAZMAT program to understand and correct baseline deficiencies in the prerequisites for attending the enhanced inspector training course.

- The CVSA continue to update and refine the ENAS inspection program as the need arises, by improved procedures or other actions as deemed appropriate by the RAM Subcommittee of the CVSA HAZMAT Committee. 
- The CVSA emphasize the importance of the ENAS Refresher Course for insuring that inspectors are following the approved inspection procedures.

- The DOE continue to emphasize and require the point of origin "defect free" inspection per the ENAS standard on all their HRCQ and TRU shipments.

- The appropriate jurisdictions conduct periodic and random inspections at the point of destination for HRCQ and TRU shipments.

- Carriers involved in HRCQ and TRU shipments have their traffic managers, mechanics and drivers attend a CVSA industry awareness course on the Level I NAS inspection program and Hazardous Materials and ENAS inspection program.

- Carriers shipping radioactive materials under the CVSA ENAS use dedicated and CVSA-trained drivers as it has been determined that such drivers have more understanding of and are responsive to the enhanced inspection process.

- Jurisdiction inspections carried out under the ENAS adhere to and follow the procedures and out-of-service criteria stipulated in the CVSA operational policies.

- Jurisdiction inspectors involved in conducting ENAS inspections adhere to all certification requirements as stipulated in the CVSA operational policies.

- Jurisdictions address the procurement of accurate and reliable radiation survey instruments including appropriate monitoring protections for their inspectors that are involved in ongoing radioactive materials inspections.

- Instructors used in the ENAS inspection or refresher courses meet the CVSA instructor requirements stipulated in the CVSA operational policies.

- Decals be affixed by a CVSA certified ENAS inspector according to the requirements stipulated in the CVSA operational policies.

- Training materials used in the CVSA ENAS inspection courses such as videos, student manuals, and presentation slides be periodically updated to reflect changes in regulations and procedures.

- Inspector training and education be offered on a continuing basis since turnover of inspection personnel does occur.

- Brochures, the display unit and other outreach materials be kept current and a supply maintained for distribution.

- The RAD Inspection News newsletter be continued as it provides a vital communications link among inspectors, CVSA, DOE, DOT, industry, and other stakeholders regarding changes in regulations, procedures and safety concerns regarding inspections and the safe transportation of radioactive materials.

- Integration of the proposed supplementary form with other inspection data collection systems to minimize the recording of identical information more than once and to take advantage of existing means of data entry.

- More emphasis be given on data collection and analysis as a means of providing input for changes in the enhanced inspection. Data collection may include conducting 
surveys of inspectors and other organizations, obtaining data from the inspection and driver interview forms, and utilizing other sources of related transportation data (e.g., Safestat).

- Funding be derived from various sources to insure that the ENAS inspection program is continued as it would be less costly than halting the program and attempting to restart it at a later date.

- The CVSA and DOE collaborate to identify ways for the ENAS program to remain viable. This includes funding for instructors and administrative costs to continue the ENAS inspection program until such time that individual state training funds are made available through the Nuclear Waste Policy Act Section 180(c), DOT funds through MCSAP are available, or until DOE's Consolidated Transportation grant is available. 


\section{APPENDIX}

Contents of Appendix

\begin{tabular}{|c|c|c|}
\hline Item \# & Description & Date \\
\hline 1 & $\begin{array}{l}\text { Summary Report on CVSA/DOE Pilot Study Data } \\
\text { Collection Results }\end{array}$ & $10 / 99$ \\
\hline 2 & $\begin{array}{l}\text { Proposal -- Development of an Inspection Procedure } \\
\text { for the Highway Transportation of Radioactive } \\
\text { Waste }\end{array}$ & $3 / 1 / 86$ \\
\hline 3 & $\begin{array}{l}\text { CVSA Proposal to Conduct a Pilot Study of the } \\
\text { Draft CVSA Highway Vehicle Inspection } \\
\text { Procedures for Transportation of Radioactive } \\
\text { Materials }\end{array}$ & $4 / 17 / 89$ \\
\hline 4 & $\begin{array}{l}\text { CVSA/DOE Cooperative Agreement Proposed } \\
\text { Statement of Work: March 1, 1994 - February 28, } \\
1999 \text { (extended to June 30, 1999) }\end{array}$ & none \\
\hline 5 & $\begin{array}{l}\text { CVSAJDOE Pilot Inspection Program -- } \\
\text { Background, Statement of Work, Sole Source } \\
\text { Justification }\end{array}$ & none \\
\hline 6 & $\begin{array}{l}\text { Cooperative Agreement between the CVSA and EM } \\
\text { NTP and WIPP }\end{array}$ & $7 / 22 / 98$ \\
\hline 7 & CVSA Pilot Study Management Plan & $\begin{array}{l}\text { not dated -draft } \\
\text { was } 6 / 25 / 90\end{array}$ \\
\hline 8 & $\begin{array}{l}\text { CVSA Pilot Inspection Study: Literature Review of } \\
\text { Inspection Issues }\end{array}$ & $2 / 91$ \\
\hline 9 & Minutes from Subcommittee Meetings & $2 / 94-5 / 99$ \\
\hline 10 & $\begin{array}{l}\text { Research Design for the DOE/CVSA Pilot Study of } \\
\text { Highway Vehicle Inspection Procedures for the } \\
\text { Transportation of Radioactive Materials }\end{array}$ & $7 / 91$ \\
\hline 11 & $\begin{array}{l}\text { Issues for DOE/CVSA Pilot Study Research Design } \\
\text { Document }\end{array}$ & $5 / 22 / 94$ \\
\hline 12 & Plan for the CVSA-DOE Pilot Inspection Study & $3 / 27 / 95$ \\
\hline 13 & Draft Data Requirements and Analysis Strategy & $3 / 15 / 91$ \\
\hline 14 & Data Validation Procedures & $3 / 31 / 93$ \\
\hline 15 & CVSA/DOE Pilot Inspection Study & $1 / 94$ \\
\hline
\end{tabular}




\begin{tabular}{|c|c|c|}
\hline Item \# & Description & Date \\
\hline 16 & $\begin{array}{l}\text { CVSA North American Standard Out-of-Service } \\
\text { Criteria and Enhanced North American Standard } \\
\text { Inspection Procedures and Out-of-Service Criteria } \\
\text { for Commercial Highway Vehicles Transporting } \\
\text { Transuranics, Spent Nuclear Fuel, and High-Level } \\
\text { Radioactive Waste (the "flipchart") }\end{array}$ & $4 / 1 / 99$ \\
\hline 17 & $\begin{array}{l}\text { Inspection Form and Instructions to Complete Data } \\
\text { Elements }\end{array}$ & $4 / 95$ \\
\hline 18 & $\begin{array}{l}\text { Point of Destination Driver Interview Form and } \\
\text { Distribution Instructions }\end{array}$ & $7 / 99$ \\
\hline 19 & RAD Inspection News Back Issues & $11 / 94-10 / 99$ \\
\hline 20 & CVSA Pilot Study Summary Brochure & $1 / 95$ \\
\hline 21 & Color Brochure & 1995 \\
\hline 22 & Videotape Cover and Description & 1994 \\
\hline 23 & Briefing to DOE Traffic Managers & $2 / 98$ \\
\hline 24 & $\begin{array}{l}\text { Cesium Transportation Campaign - Report on } \\
\text { CVSA/DOE Pilot Study Inspection Activities }\end{array}$ & $9 / 95$ \\
\hline 25 & $\begin{array}{l}\text { LSA/Nitric Acid Transportation Campaign - Report } \\
\text { on CVSA/DOE Pilot Study Inspection Activities }\end{array}$ & $4 / 96$ \\
\hline 26 & CVSA Pilot Study Checklist & $4 / 96$ \\
\hline 27 & $\begin{array}{l}\text { Safe Routine Transportation of DOE's Radioactive } \\
\text { Materials (JTA) }\end{array}$ & 1997 \\
\hline 28 & $\begin{array}{l}\text { North American Standard Level I Inspection } \\
\text { Procedures and Out-of-Service Criteria Industry } \\
\text { Awareness Course for WIPP - Course Agenda }\end{array}$ & none \\
\hline 29 & Issue: Indian Tribal Membership in CVSA & $3 / 24 / 96$ \\
\hline 30 & $\begin{array}{l}\text { CVSA - Native American Tribal Pilot Inspection } \\
\text { Proposal: Train a Select Cadre of Native American } \\
\text { Tribal Members to Conduct Safety Inspections of } \\
\text { Motor Carrier Transporters of Radioactive Materials }\end{array}$ & $3 / 96$ \\
\hline 31 & $\begin{array}{l}\text { Letter: WGA to CVSA Concerning Incorporation of } \\
\text { Enhanced Procedures in the WGA's WIPP } \\
\text { Transportation Safety Program Implementation Plan }\end{array}$ & $5 / 1 / 97$ \\
\hline 32 & $\begin{array}{l}\text { CVSA/DOE Standing Subcommittee of the } \\
\text { HAZMAT Committee, Recommendation of CVSA } \\
\text { Enhanced North American Standard Inspection } \\
\text { Procedures and Out-of-Service Criteria }\end{array}$ & $5 / 97$ \\
\hline
\end{tabular}


Item \#

Description

Date

33 Carrier Questionnaire and Responses

3/99-5/99

34 CVSA Operational Policies (includes Memorandum

of Understanding)

$8 / 1 / 99$

35 Proposed Form to Supplement MCSAP

10/99

SAFETYNET 
Summary Report on CVSA/DOE Pilot Study. Data Collection Results 


\title{
SUMMARY REPORT ON CVSA/DOE PILOT STUDY DATA COLLECTION RESULTS
}

\author{
Prepared by \\ Commercial Vehicle Safety Alliance
}

October 1999

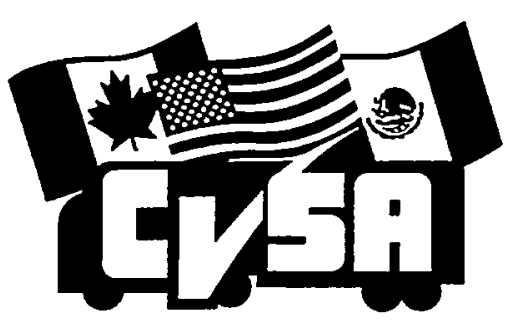


For information concerning this report, contact:

Commercial Vehicle Safety Alliance

5430 Grosvenor Lane, Suite 130

Bethesda, MD 20814

Phone: (301) 564-1623

Fax: (301) 564-0588 


\section{EXECUTIVE SUMMARY}

Since 1986 the Commercial Vehicle Safety Alliance (CVSA) has worked with the United States Department of Energy (DOE) under a cooperative agreement to develop and maintain uniform inspection procedures for vehicles, drivers and cargo involved in the transportation of spent fuel and high-level radioactive waste. These procedures are known as the Enhanced North American Standard (ENAS) inspection procedures. As part of the cooperative agreement, CVSA conducted a pilot study to evaluate the soundness of the procedures, develop training curricula, conduct training, perform inspections and generate evaluations that could support recommendations concerning the frequency of inspections and the factors that contribute to shipment safety. This report summarizes the enhanced inspection data collected under the CVSA/DOE Pilot Study. These data were collected from select shipping campaigns and other shipments that occurred between May 1994 and September 1999. The report presents findings for each campaign and overall results and comparisons.

Based on the Pilot Study findings, the following are the main conclusions and recommendations concerning safety and efficiency in the transportation of radioactive materials and the viability of the enhanced inspection program.

- Based on the limited data available from the shipping campaigns it is concluded that en route inspections are generally not needed unless required by a jurisdiction's regulation. It was also determined that most jurisdictions, once advised of the requirements of the ENAS, will honor the decal and grant reciprocity.

- The ENAS "defect free" requirement at the point of origin insures that vehicle, driver, and cargo will arrive at the destination with minor or no safety violations.

- Good brake and placard maintenance by carriers would reduce the number of violations.

- A strong commitment by shippers to include the enhanced inspection procedures in transportation plans and operations is needed to insure a viable and efficient inspection program.

- The ENAS should be used only on select shipments such as highway route controlled quantity shipments of radioactive materials and the WIPP shipments. It should not be used on low level shipments.

- Carriers shipping radioactive materials under the ENAS should use dedicated drivers and should have their traffic managers, mechanics, and drivers attend a CVSA industry awareness course on the Level I North American Standard inspection program and Hazardous Materials, and ENAS inspection program.

- DOE should continue to emphasize and include ENAS point of origin "defect free" inspections in the protocols for their highway route controlled quantity shipments of radioactive materials and transuranics shipments in order to address public concerns about the safety of such shipments. 



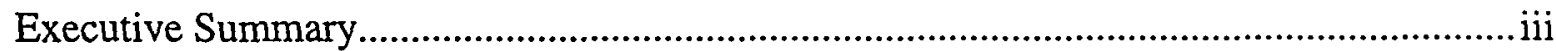

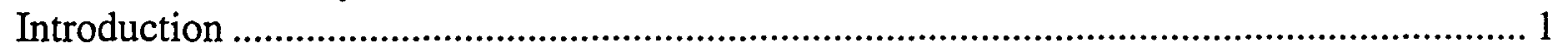

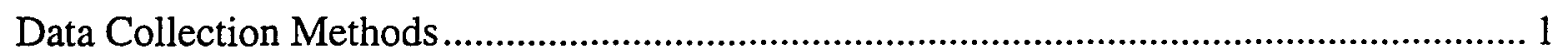

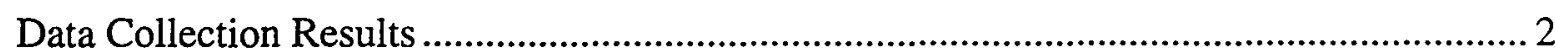

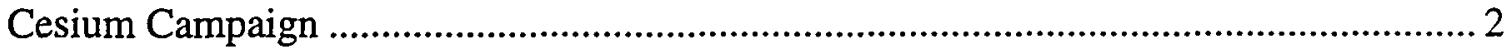

LSA/Nitric Acid Campaign ...................................................................................... 4

Brookhaven - Savannah River Campaign ..................................................................... 6

Oak Ridge - Savannah River Campaign......................................................................... 7

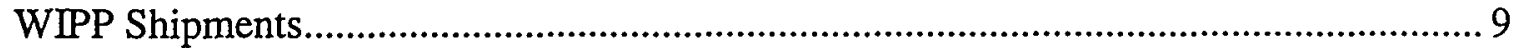

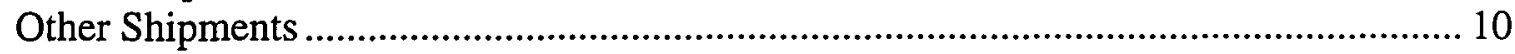

Overall Results and Comparisons ............................................................................... 13

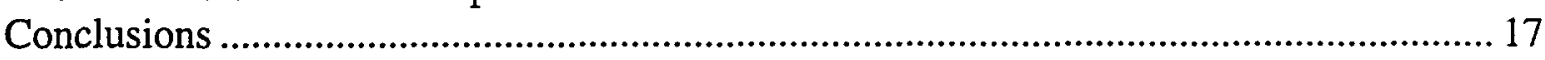

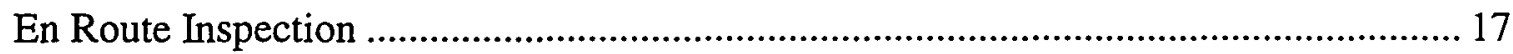

Point of Origin Inspection ...................................................................................... 17

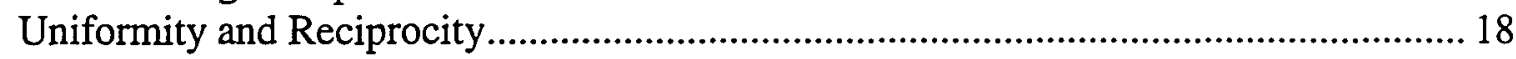

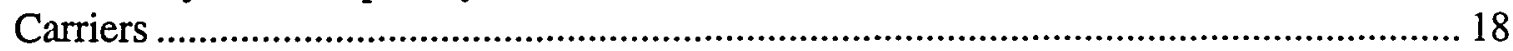

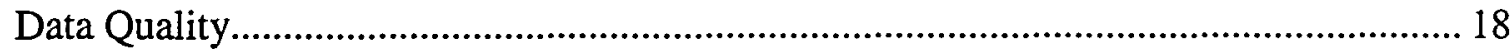

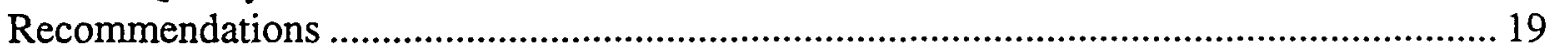

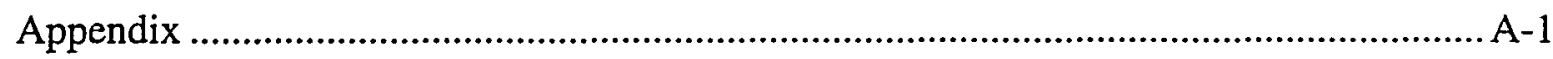


Table 1. Cesium Campaign: Number of enhanced inspections by state 3

Table 2. Cesium Campaign inspections: Summary of violations by description and

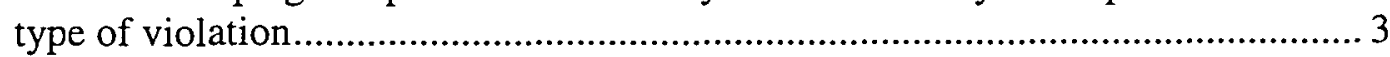

Table 3. LSANitric Acid Campaign: Number of enhanced inspections by state ................ 5

Table 4. LSANitric Acid Campaign inspections: Summary of violations by description and type of violation

Table 5. Brookhaven - Savannah River Campaign inspections: Summary of violations by description and type of violation

Table 6. Oak Ridge - Savannah River Campaign point of origin inspections: Summary of violations by description and type of violation.

Table 7. Oak Ridge - Savannah River Campaign point of destination inspections: Summary of violations by description and type of violation ................................... 8

Table 8. Oak Ridge - Savannah River Campaign en route inspection: Summary of violations by description and type of violation ................................................... 9

Table 9. WIPP shipments: Number of enhanced inspections by state ................................ 10

Table 10.WIPP inspections: Summary of violations by description and type of violation

Table 11. Other shipments: Number of enhanced inspections by state ............................. 11

Table 12. Other inspections: Summary of violations by description and type of

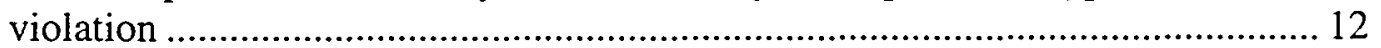

Table 13. Overall summary of violations by description and type of violation................... 14

Table 14. Overall rank of violations by description and type of violation ......................... 15

Table 15. Overall summary of violations by location of inspection and type of violation

Table 16. Number of enhanced inspections by carrier and most severe violation type found 


\section{SUMMARY REPORT ON CVSA/DOE PILOT STUDY DATA COLLECTION RESULTS}

\section{INTRODUCTION}

Since 1986 the Commercial Vehicle Safety Alliance (CVSA) has worked with the United States Department of Energy (DOE) under a cooperative agreement to develop and maintain uniform inspection procedures for vehicles, drivers and cargo involved in the transportation of spent fuel and high-level radioactive waste. These procedures are known as the Enhanced North American Standard (ENAS) inspection procedures. As part of the cooperative agreement CVSA conducted a pilot study to evaluate the soundness of the procedures, develop training curricula, conduct training, perform inspections and generate evaluations that could support recommendations concerning the frequency of inspections and the factors that contribute to shipment safety. The Pilot Study concluded on June 30, 1999.

This report provides a summary of selected results from the data collection activities conducted under the CVSA/DOE Pilot Study. The earliest Pilot Study data collection efforts began in 1992. However these were often sporadically applied and it was not until specific shipping campaigns were identified that required the use of the data collection forms that a more consistent approach to data collection was achieved. Thus this report considers only data collected from identified shipping campaigns, beginning with the Cesium Campaign in May 1994, and data collected from other shipments (not identified with specific campaigns), beginning in January 1997, up until the end of the Pilot Study in June 1999 (with the exception of the WIPP shipment data which is reported through September 30, 1999).

The following two sections of the report describe the methods used to collect data on the inspection activities and the findings of these data collection efforts, presented first for each campaign and then over all the campaigns. The report concludes with a discussion of the implications of the findings and recommendations for future actions.

\section{DATA COLLECTION METHODS}

Under the Pilot Study data collection had been primarily through the use of two forms. The CVSA/DOE Spent Fuel/Transuranic/High Level Radioactive Waste Pilot Study Inspection Form was used to record the enhanced inspection data. It was first printed in December 1991 and was revised in April 1995. A copy of the current form and the instructions for completing the form are in the Appendix. The Point of Destination Driver Interview Form was used to collect data from the drivers of the vehicle on the inspections, events, and problems encountered during the trip. It is given to the drivers by the enhanced inspector at the point of origin. This form was initially printed in January 1992. A copy of the current version of the form and the instructions for distributing the form are in the Appendix. Supplemental information on the CVSA inspection criteria and possible enforcement actions for violations is also provided in the Appendix. 


\section{DATA COLLECTION RESULTS}

The original design of the Pilot Study called for detailed data collection activities and complex analyses for spent fuel shipments. Because no spent fuel shipments were available in significant numbers, the study was based on the characteristics of the Waste Isolation Pilot Plant (WIPP) transportation campaign which consists of shipments transporting radioactive waste to a repository at Carlsbad, New Mexico. Other DOE radioactive shipments were identified that could be used for enhanced inspections that would utilize the inspection and driver interview forms in order to supplement WIPP shipment data. To date, the results of two of the transportation campaigns that have been used, the Cesium and LSA/Nitric Acid transportation campaigns, have been documented in separate reports. ' Other sources of data include the Brookhaven - Savannah River and Oak Ridge - Savannah River spent fuel transportation campaigns, the WIPP shipments, and enhanced inspections conducted by the states on other shipments. These data are summarized in this report in order to give a full picture of the Pilot Study results.

The Pilot Study Inspection Form and the Point of Destination Driver Interview Form have been the primary data collection tools. On occasion, surveys and interviews with inspectors and drivers have also been conducted. The following subsections describe the results of these data collection activities.

\section{Cesium Campaign}

This campaign began with 20 shipments of cesium capsules from the IOTECH facility in Northglenn, Colorado to the Hanford site in Washington State. These shipments were conducted over the course of one year beginning in May 1994. Enhanced inspections were conducted at the point of origin, the point of destination and at locations en route during each shipment. Data were collected on the inspections using inspection forms and driver interview forms. Utilizing surveys and interviews with inspectors and drivers, data were collected on various components of the inspection process such as training, conduct of inspections, and attitudes regarding enhanced inspections. A report titled Cesium Transportation Campaign: Report on CVSA/DOE Pilot Study Inspection Activities was prepared in September 1995 on this part of the campaign. Two final shipments of cesium capsules from Lynchburg, Virginia to Hanford were conducted in 1996 and the inspection results for these shipments were documented in the October 1996 issue of the RAD Inspection News newsletter. ${ }^{2}$

\footnotetext{
${ }^{1}$ The two transportation campaign reports, Cesium Transportation Campaign: Report on CVSADDOE Pilot Study Inspection Activities and LSANitric Acid Transportation Campaign: Report on CVSA/DOE Pilot Study Inspection Activities, as well as this report can be found in the appendix to the document CVSA/DOE Cooperative Agreement Final Report which is a summary report of activities conducted under the CVSA/DOE Cooperative Agreement. Requests for copies of the reports may be made to CVSA Headquarters, 5430 Grosvenor Lane, Suite 130, Bethesda, MD 20814, (301) 564-1623.

2 The report, Cesium Transportation Campaign: Report on CVSA/DOE Pilot Study Inspection Activities, and the October 1996 issue of the RAD Inspection News can be found in the appendix to the document CVSA/DOE Cooperative Agreement Final Report.
} 
For this campaign of 22 shipments a summary of the total number of inspections by state is given in Table 1 and a summary of the number and types of violations found during the inspections is given in Table 2 . $^{3}$

Table 1. Cesium Campaign: Number of enhanced inspections by state

\begin{tabular}{l|c}
\hline \multicolumn{1}{c|}{ State } & Number of Inspections \\
\hline Colorado & 23 \\
\hline Wyoming & 2 \\
\hline Idaho & 20 \\
\hline Oregon & 20 \\
\hline Washington & 21 \\
\hline Virginia & 2 \\
\hline \hline TOTAL Number of Inspections & $\mathbf{8 8}$ \\
\hline
\end{tabular}

Table 2. Cesium Campaign inspections: Summary of violations by description and type of violation

\begin{tabular}{|c|c|c|c|c|}
\hline \multirow[b]{2}{*}{$\begin{array}{c}\text { Description of } \\
\text { Defect/Violation }\end{array}$} & \multirow[b]{2}{*}{$\begin{array}{l}\text { Not Out-of- } \\
\text { Service } \\
\text { Violations }\end{array}$} & \multicolumn{3}{|c|}{ Out-of-Service Violations } \\
\hline & & $\begin{array}{c}\text { North } \\
\text { American } \\
\text { Standard } \\
\end{array}$ & $\begin{array}{l}\text { Enhanced } \\
\text { North } \\
\text { American } \\
\text { Standard } \\
\end{array}$ & $\begin{array}{c}\text { Total Out-of- } \\
\text { Service }\end{array}$ \\
\hline $\begin{array}{l}\text { Brakes } \\
\text { Out of adjustment } \\
\text { Line air leaks } \\
\text { Line chaffing } \\
\text { Gladhand leaks } \\
\text { Chamber moisture } \\
\text { Loose jamnut }\end{array}$ & $\begin{array}{l}2 \\
1\end{array}$ & & $\begin{array}{l}7^{*} \\
3 \\
1 \\
1\end{array}$ & $\begin{array}{l}7 \\
3 \\
1 \\
1\end{array}$ \\
\hline $\begin{array}{l}\text { Exhaust } \\
\text { Leaks }\end{array}$ & 2 & 1 & & 1 \\
\hline $\begin{array}{l}\text { Lights } \\
\quad \text { Turn signal } \\
\text { Clearance lights }\end{array}$ & 1 & 2 & & 2 \\
\hline $\begin{array}{l}\text { Miscellaneous } \\
\text { Placard } \\
\text { Loose turnbuckle at cask connection } \\
\text { Loose bolts } \\
\text { Dead battery } \\
\end{array}$ & $\begin{array}{l}1 \\
2 \\
1 \\
\end{array}$ & & 1 & 1 \\
\hline TOTALS & 10 & 3 & 13 & 16 \\
\hline Total Number of Inspections $=88$ & & & & \\
\hline
\end{tabular}

${ }^{3}$ Definitions of violation types are given in the Inspections and Enforcement section of the Appendix. 
The following summarizes the most important observations from this campaign.

- The campaign was a success according to the inspectors and drivers which they believed was due to factors including the use of a transportation plan, the enhanced inspection criteria, and trained and dedicated drivers; a responsible carrier; and cooperation among the inspectors and drivers.

- A low rate of out-of-service violations (when compared to the national average) was found during the campaign.

- Inspectors and drivers expressed confidence in the enhanced inspection procedures and believed that the inspection procedures should be used on all high level radioactive waste shipments, including those for spent nuclear fuel.

- Inspectors felt that the requirement for enhanced inspections promotes better equipment and drivers.

- Inspectors believed that if the public were made more aware of the enhanced inspection activities and what is being accomplished to ensure safety in the transportation of radioactive materials, then there would be less cause for concern on the part of the public.

\section{LSA/Nitric Acid Campaign}

This campaign consisted of 25 paired shipments (total of 50) of Low Specific Activity (LSA)/nitric acid from Hanford, Washington to Portsmouth, Virginia. From Portsmouth, the LSA/nitric acid was then transported via ocean carrier to Great Britain for processing. The shipments were conducted from May through November 1995. Enhanced inspections were conducted at the point of origin, the point of destination and, on three occasions, en route during shipment. Data were collected on the inspections using inspection forms and driver interview forms. Utilizing surveys and interviews with inspectors and drivers, data were collected on various components of the inspection process such as training, conduct of inspections, and attitudes regarding enhanced inspections. A report titled LSANitric Acid Transportation Campaign: Report on CVSA/DOE Pilot Study Inspection Activities was prepared in April 1996 on this campaign. ${ }^{4}$

For this campaign of 50 shipments a summary of the total number of inspections by state is given in Table 3 and a summary of the number and types of violations found during the inspections is given in Table $4 .^{5}$

\footnotetext{
${ }^{4}$ The report, LSA/Nitric Acid Transportation Campaign: Report on CVSA/DOE Pilot Study Inspection Activities, can be found in the appendix to the document CVSA/DOE Cooperative Agreement Final Report.

${ }^{5}$ A total of 40 package marking violations were originally reported for the LSA/Nitric Acid Campaign. It was subsequently determined that these were not violations but inconsistencies at the point of destination in interpreting the radioactive markings on the vehicles. Thus these 40 "violations" are not included in this report.
} 
Table 3. LSA/Nitric Acid Campaign: Number of enhanced inspections by state

\begin{tabular}{l|c}
\hline \multicolumn{1}{c|}{ State } & Number of Inspections \\
\hline Washington & 51 \\
\hline Idaho & 3 \\
\hline Maryland & 5 \\
\hline Virginia & 45 \\
\hline TOTAL Number of Inspections & 104 \\
\hline \hline
\end{tabular}

Table 4. LSA/Nitric Acid Campaign inspections: Summary of violations by description and type of violation

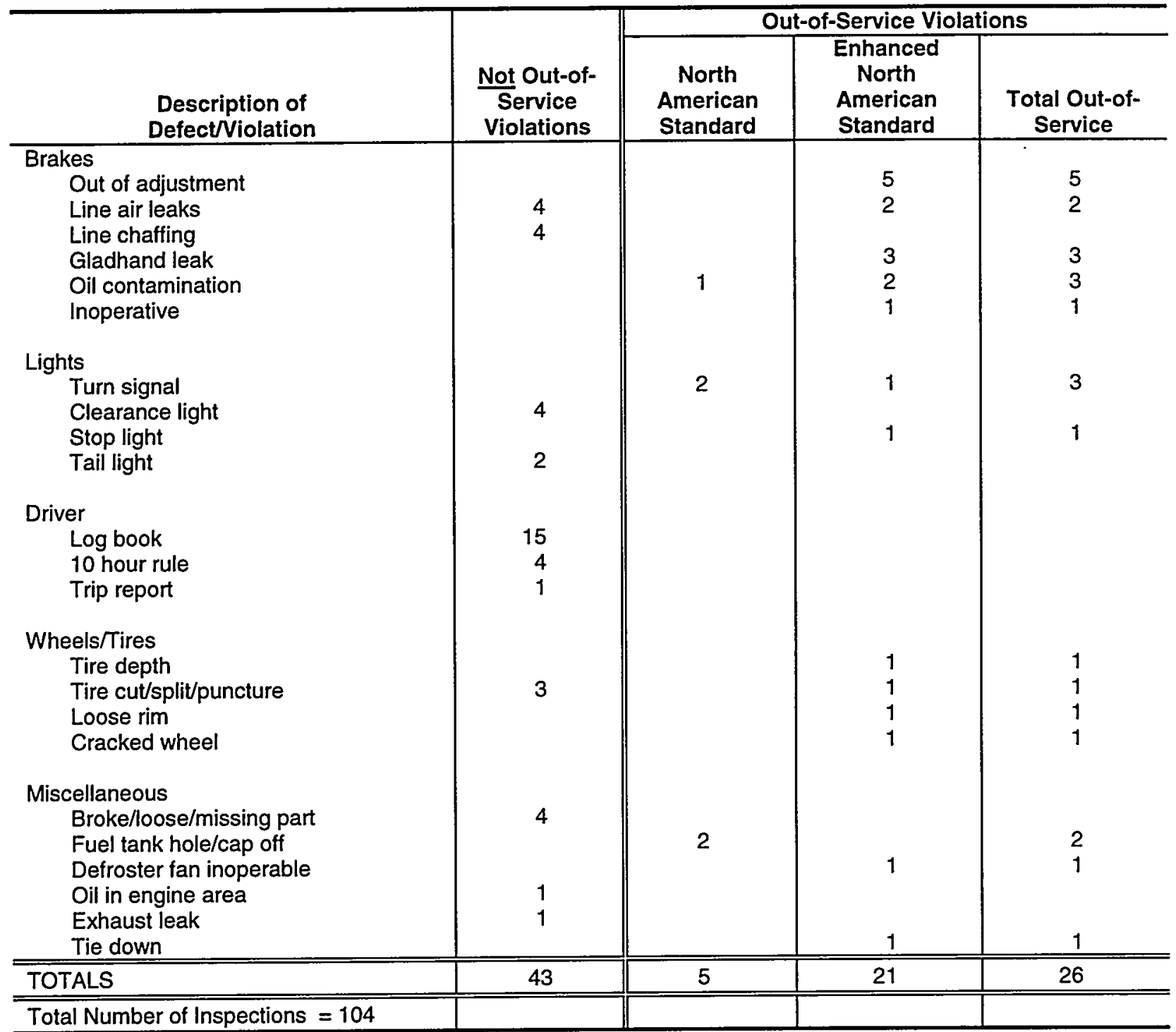


The following summarizes the most important observations from this campaign.

- Out of 104 enhanced inspections, there were a total of 26 out-of-service violations of which 21 were enhanced out-of-service violations.

- Vehicle equipment problems were generally fixed promptly. Both inspectors and drivers noted that communications among the drivers, carrier, and the inspectors and scheduling of the arrival and inspection of vehicles could be improved.

- Inspectors and drivers expressed confidence in the enhanced inspection procedures and believed that the inspection procedures should be used on all high level radioactive shipments.

- Inspectors felt that the enhanced training was sufficient to allow them to complete thorough enhanced inspections.

\section{Brookhaven - Savannah River Campaign}

This campaign consisted of five shipments of five vehicles each (total of 25) of spent nuclear fuel from Brookhaven Laboratory on Long Island, New York to Savannah River, South Carolina. The shipments were conducted from December 1996 through September 1997. Casks were transported by vehicles from Brookhaven Laboratory, unloaded onto lake barges (approximately 9 miles away) and then ferried to Portsmouth, Virginia. At Portsmouth the casks were reloaded onto the vehicles (which were driven from the point of embarkation to Portsmouth) and the units were inspected for transportation to South Carolina. The plan was to have enhanced point of origin inspections in New York by Virginia State Police, en route inspections in Portsmouth and point of destination inspections at Savannah River, South Carolina. It was later decided that county inspectors, trained only in the North American Standard inspection procedures, would do inspections at the point of origin. The CVSA enhanced inspections would be done at Portsmouth by Virginia inspectors (i.e., the enhanced point of origin inspections) and at the point of destination in South Carolina by South Carolina inspectors. In reality 25 inspection forms were received from Virginia covering the point of origin inspections for each of the 25 shipments. Also three driver interview forms were received, and these indicated that there were no problems or concerns for the three shipments.

For this campaign of 25 shipments a summary of the number and types of violations found during the 25 point of origin inspections by Virginia inspectors is given in Table 5 . 
Table 5. Brookhaven - Savannah River Campaign inspections: Summary of violations by description and type of violation

\begin{tabular}{|c|c|c|c|c|}
\hline \multirow[b]{2}{*}{$\begin{array}{l}\text { Description of } \\
\text { Defect/Violation }\end{array}$} & \multirow[b]{2}{*}{$\begin{array}{l}\text { Not Out-of- } \\
\text { Service } \\
\text { Violations }\end{array}$} & \multicolumn{3}{|c|}{ Out-of-Service Violations } \\
\hline & & $\begin{array}{c}\text { North } \\
\text { American } \\
\text { Standard } \\
\end{array}$ & $\begin{array}{l}\text { Enhanced } \\
\text { North } \\
\text { American } \\
\text { Standard } \\
\end{array}$ & $\begin{array}{c}\text { Total Out-of- } \\
\text { Service }\end{array}$ \\
\hline $\begin{array}{l}\text { Brakes } \\
\text { Out of adjustment } \\
\text { Line air leaks } \\
\text { Inoperative }\end{array}$ & 2 & 1 & $\begin{array}{l}1 \\
3\end{array}$ & $\begin{array}{l}1 \\
3 \\
1\end{array}$ \\
\hline $\begin{array}{l}\text { Driver } \\
\text { Log book } \\
\text { Permit }\end{array}$ & $\begin{array}{l}3 \\
1\end{array}$ & & & \\
\hline $\begin{array}{l}\text { Wheels/Tires } \\
\text { Tire puncture } \\
\text { Loose bolt }\end{array}$ & & & $\begin{array}{l}1 \\
1\end{array}$ & $\begin{array}{l}1 \\
1\end{array}$ \\
\hline $\begin{array}{l}\text { Miscellaneous } \\
\text { Loose shock absorber }\end{array}$ & 1 & & & \\
\hline TOTALS & 7 & 1 & 6 & 7 \\
\hline Total Number of Inspections $=25$ & & & & \\
\hline
\end{tabular}

The following summarizes the most important observations from this campaign.

- Using county police and North American Standard inspection procedures at the initial point of origin at Brookhaven provided uniqueness to the Pilot Study that is not recommended for future shipments. If ENAS inspections had been conducted at Brookhaven, it is likely that inspectors would have detected and insured correction of violations which were later discovered at the Virginia site.

- The motor carrier needs to address brake and driver log book problems.

\section{Oak Ridge - Savannah River Campaign}

This campaign consists of approximately monthly shipments of spent nuclear fuel from Oak Ridge National Laboratory in Tennessee to Savannah River Site in South Carolina. The shipments began in July 1996 and are currently ongoing. Point of origin enhanced inspections are conducted by Tennessee inspectors and point of destination enhanced inspections are conducted by South Carolina inspectors. As of June 30, 1999, a total of 59 inspection forms have been received ( 36 from Tennessee, 22 from South Carolina, and 1 from Georgia) covering 38 shipments. In addition, 23 driver interview forms have been received. These driver data generally indicate that there were no problems or concerns for the shipments.

For the 38 shipments for which data have been received, summaries of the number and types of violations found during the 36 point of origin inspections by Tennessee inspectors, 
22 point of destination inspections by South Carolina inspectors, and 1 en route inspection by Georgia inspectors are given in Table 6, Table 7, and Table 8, respectively.

Table 6. Oak Ridge - Savannah River Campaign point of origin inspections: Summary of violations by description and type of violation

\begin{tabular}{|c|c|c|c|c|}
\hline \multirow[b]{2}{*}{$\begin{array}{l}\text { Description of } \\
\text { Defect/Violation }\end{array}$} & \multirow[b]{2}{*}{$\begin{array}{l}\text { Not Out-of- } \\
\text { Service } \\
\text { Violations }\end{array}$} & \multicolumn{3}{|c|}{ Out-of-Service Violations } \\
\hline & & $\begin{array}{l}\text { North } \\
\text { American } \\
\text { Standard }\end{array}$ & $\begin{array}{l}\text { Enhanced } \\
\text { North } \\
\text { American } \\
\text { Standard }\end{array}$ & $\begin{array}{l}\text { Total Out-of- } \\
\text { Service }\end{array}$ \\
\hline $\begin{array}{l}\text { Brakes } \\
\text { Yoke not attached to push rod } \\
\text { Exposed service/emergency hose }\end{array}$ & & & $\begin{array}{l}1 \\
2\end{array}$ & $\begin{array}{l}1 \\
2\end{array}$ \\
\hline $\begin{array}{c}\text { Wheels/Tires } \\
\text { Flat tire }\end{array}$ & & 1 & & 1 \\
\hline $\begin{array}{l}\text { Miscellaneous } \\
\text { Placard } \\
\text { Unprotected quick release } \\
\text { Exposed steering hose } \\
\end{array}$ & & & $\begin{array}{l}5 \\
1 \\
1 \\
\end{array}$ & $\begin{array}{l}5 \\
1 \\
1 \\
\end{array}$ \\
\hline TOTALS & 0 & 1 & 10 & 11 \\
\hline Total Number of Inspections $=36$ & & & & \\
\hline
\end{tabular}

Table 7. Oak Ridge - Savannah River Campaign point of destination inspections: Summary of violations by description and type of violation

\begin{tabular}{|c|c|c|c|c|}
\hline \multirow[b]{2}{*}{$\begin{array}{l}\text { Description of } \\
\text { Defect/Violation }\end{array}$} & \multirow[b]{2}{*}{$\begin{array}{l}\frac{\text { Not Out-of- }}{\text { Service }} \\
\text { Violations }\end{array}$} & \multicolumn{3}{|c|}{ Out-of-Service Violations } \\
\hline & & $\begin{array}{l}\text { North } \\
\text { American } \\
\text { Standard }\end{array}$ & $\begin{array}{l}\text { Enhanced } \\
\text { North } \\
\text { American } \\
\text { Standard }\end{array}$ & $\begin{array}{l}\text { Total Out-of- } \\
\text { Service }\end{array}$ \\
\hline $\begin{array}{l}\text { Driver } \\
\text { Log book } \\
\text { Missing document/number }\end{array}$ & $\begin{array}{l}1 \\
2\end{array}$ & & & \\
\hline $\begin{array}{l}\text { Wheels/Tires } \\
\text { Tire air leak }\end{array}$ & 1 & & & \\
\hline $\begin{array}{l}\text { Lights } \\
\text { Turn, hazard, brake inoperative }\end{array}$ & & & 1 & 1 \\
\hline $\begin{array}{l}\text { Miscellaneous } \\
\text { Engine oil leak } \\
\text { Tie down unfastened } \\
\end{array}$ & $\begin{array}{l}3 \\
1 \\
\end{array}$ & & & \\
\hline TOTALS & 8 & 0 & 1 & 1 \\
\hline Total Number of Inspections $=22$ & & & & \\
\hline
\end{tabular}


Table 8. Oak Ridge - Savannah River Campaign en route inspection: Summary of violations by description and type of violation

\begin{tabular}{|c|c|c|c|c|}
\hline \multirow[b]{2}{*}{$\begin{array}{l}\text { Description of } \\
\text { Defect/Violation }\end{array}$} & \multirow[b]{2}{*}{$\begin{array}{l}\text { Not Out-of- } \\
\text { Service } \\
\text { Violations }\end{array}$} & \multicolumn{3}{|c|}{ Out-of-Service Violations } \\
\hline & & $\begin{array}{c}\text { North } \\
\text { American } \\
\text { Standard }\end{array}$ & $\begin{array}{l}\text { Enhanced } \\
\text { North } \\
\text { American } \\
\text { Standard }\end{array}$ & $\begin{array}{l}\text { Total Out-of- } \\
\text { Service }\end{array}$ \\
\hline $\begin{array}{l}\text { Wheels/Tires } \\
\text { Tire missing tread (blow out) }\end{array}$ & & 1 & & \\
\hline TOTALS & 0 & 1 & 0 & 1 \\
\hline Total Number of Inspections $=1$ & & & & \\
\hline
\end{tabular}

The following summarizes the most important observations from this campaign to date.

- A number of placarding and equipment items were detected and repaired at the point of origin. The carrier needs to address the condition of placards used.

- At the point of destination only one out-of-service violation was detected on an equipment item which is recognized as an item that could become inoperative at any time.

- The data collected so far appear to support the importance of the Enhanced North American Standard for identifying violation items, and once these items are corrected at the point of origin they generally remain fixed until reaching the point of destination.

- The violation items detected at the point of origin are important for the safe transportation of radioactive materials.

\section{WIPP Shipments}

These shipments include those to the WIPP facility as well as shipments using WIPP equipment. A total of 87 inspection forms received between January 1, 1997 and September 30, 1999 are utilized for this summary. Since January 1997, 11 inspection forms have been received from Idaho for point of origin and point of destination enhanced inspections of shipments within the INEEL site. In May 1997 a shipment from New Jersey to Rocky Flats in Colorado utilized the TRUPACT II and WIPP Transportation System. New Jersey conducted the point of origin enhanced inspection and Colorado conducted the point of destination inspection. The remaining inspection forms cover point of origin, en route and point of destination inspections of shipments to the WIPP facility. Also to date, 37 driver interview forms have been received. These driver data generally provide information on weather conditions, equipment operations, and road conditions during the shipments.

For the WIPP shipments, Table 9 summarizes the number of inspections by state and Table 10 summarizes the number and types of violations found during the inspections. 
Table 9. WIPP shipments: Number of enhanced inspections by state

\begin{tabular}{l|c}
\hline \multicolumn{1}{c|}{ State } & Number of Inspections \\
\hline Colorado & 15 \\
\hline Idaho & 18 \\
\hline New Mexico & 53 \\
\hline New Jersey & 1 \\
\hline TOTAL Number of Inspections & 87 \\
\hline
\end{tabular}

Table 10. WIPP inspections: Summary of violations by description and type of violation

\begin{tabular}{|c|c|c|c|c|}
\hline \multirow[b]{2}{*}{$\begin{array}{l}\text { Description of } \\
\text { Defect/Violation }\end{array}$} & \multirow[b]{2}{*}{$\begin{array}{l}\text { Not Out-of- } \\
\text { Service } \\
\text { Violations }\end{array}$} & \multicolumn{3}{|c|}{ Out-of-Service Violations } \\
\hline & & $\begin{array}{c}\text { North } \\
\text { American } \\
\text { Standard }\end{array}$ & $\begin{array}{l}\text { Enhanced } \\
\text { North } \\
\text { American } \\
\text { Standard }\end{array}$ & $\begin{array}{l}\text { Total Out-of- } \\
\text { Service }\end{array}$ \\
\hline $\begin{array}{l}\text { Brakes } \\
\text { Air line kink } \\
\text { Gladhand leak }\end{array}$ & 1 & & 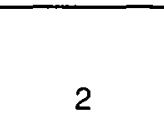 & +2 \\
\hline $\begin{array}{l}\text { Driver } \\
\qquad 10 \text { hour rule } \\
\text { Documentation }\end{array}$ & $\begin{array}{l}1 \\
1\end{array}$ & & & \\
\hline $\begin{array}{c}\text { Miscellaneous } \\
\text { Loose bolt } \\
\text { Placard } \\
\end{array}$ & 1 & & 1 & 1 \\
\hline TOTALS & 4 & 0 & 3 & 3 \\
\hline Total Number of Inspections $=87$ & & & & \\
\hline
\end{tabular}

The following summarizes the most important observations from these shipments to date.

- Out of the 87 inspections there were 3 enhanced out-of-service violations. Two of these violations were identified en route and the third was identified at the point of origin.

- The not out-of-service equipment violations are relatively minor.

- The first cross country WIPP shipment from New Jersey to Colorado exemplifies what can occur when the Enhanced North American Standard is used on the unit at the point of origin and the unit is expedited without en route inspections to arrive at the point of destination with no violations.

- The WIPP shipments have been carried out safely and efficiently and are an excellent example of the benefits of following the enhanced procedures.

\section{Other Shipments}

Several inspection forms have been received since January 1997 which are not identified with specific shipments or campaigns. Thus they are classified as "other shipments". From January 1, 1997 to June 30, 1999 a total of 76 other inspection forms have been 
received. Of these 76 forms, 15 forms have been excluded from this summary because the data are incomplete (i.e., 11 forms from Oregon and 2 forms from Ohio do not have brake measurements) or have been designated as not being enhanced inspections ( 2 Oregon forms).

For the Other shipments, Table 11 summarizes the number of inspections by state and Table 12 summarizes the number and types of violations found during the inspections.

Table 11. Other shipments: Number of enhanced inspections by state

\begin{tabular}{l|c}
\hline \hline \multicolumn{1}{c|}{ State } & Number of Inspections \\
\hline lowa & 3 \\
\hline Idaho & 4 \\
\hline New Mexico & 7 \\
\hline Ohio & 10 \\
\hline Oregon & 28 \\
\hline South Carolina & 4 \\
\hline Tennessee & 4 \\
\hline Washington & 1 \\
\hline TOTAL Number of Inspections & 61 \\
\hline \hline
\end{tabular}


Table 12. Other inspections: Summary of violations by description and type of violation

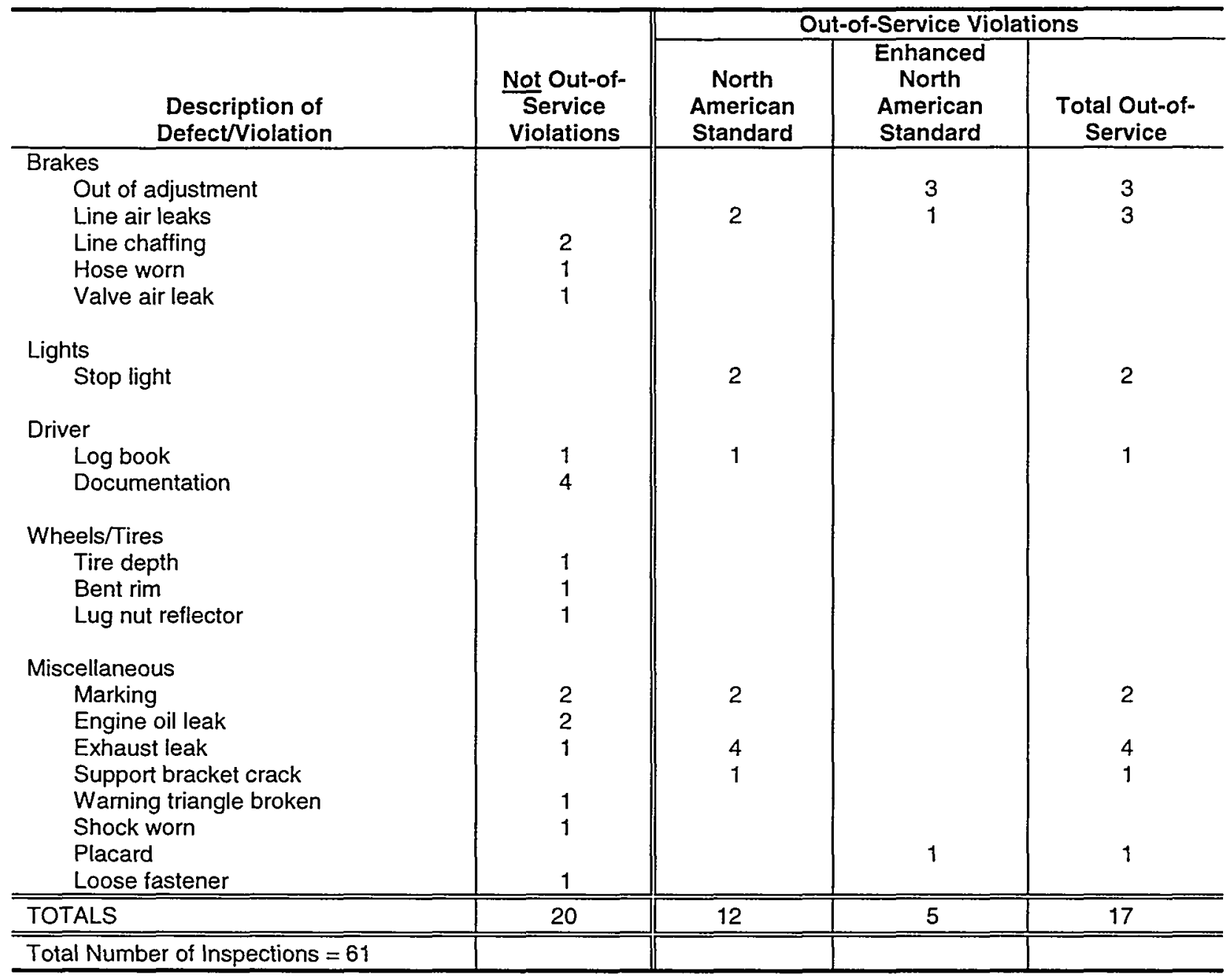

The following summarizes the most important findings from these shipments.

- Since these inspections are not associated with known campaigns it is not certain that they were actual inspections or inspections conducted for other reasons such as learning exercises.

- It is not possible to determine for each actual inspection certain basic characteristics of the inspection (such as if it was a point of origin, en route, or point of destination inspection) or of its associated shipment (e.g., where did it originate, where were other inspections conducted, etc.).

- Because of the unknown characteristics of these inspections, the data should not be combined with other inspection form data in order to derive meaningful conclusions about the enhanced inspections.

- Inspectors were encouraged to practice the ENAS inspection procedures on radioactive shipments that were not part of specific shipping campaigns and they were not to hold 
the carriers to the enhanced standard. Thus these inspections reflect the various violations and out-of-service items found and have no direct bearing on any shipping campaign.

\section{Overall Results and Comparisons}

Table 13 presents a "roll up" summary of the number and types of violations found during the enhanced inspections for the Cesium, LSA/Nitric Acid, Brookhaven - Savannah River, and Oak Ridge - Savannah River campaigns and the WIPP shipments. Because of the uncertainties associated with the Other Shipments category of enhanced inspections, these data have been excluded from this summary. From a total of 363 inspections there are 137 violations, of which 11 are North American Standard out-of-service violations and 54 are Enhanced North American Standard out-of-service violations. 
Table 13. Overall summary of violations by description and type of violation

\begin{tabular}{|c|c|c|c|c|}
\hline \multirow[b]{2}{*}{$\begin{array}{c}\text { Description of } \\
\text { DefectViolation }\end{array}$} & \multirow[b]{2}{*}{$\begin{array}{l}\text { Not Out-of- } \\
\text { Service } \\
\text { Violations } \\
\end{array}$} & \multicolumn{3}{|c|}{ Out-of-Service Violations } \\
\hline & & $\begin{array}{c}\text { North } \\
\text { American } \\
\text { Standard }\end{array}$ & $\begin{array}{l}\text { Enhanced } \\
\text { North } \\
\text { American } \\
\text { Standard } \\
\end{array}$ & $\begin{array}{c}\text { Total Out-of- } \\
\text { Service }\end{array}$ \\
\hline $\begin{array}{l}\text { Brakes } \\
\text { Out of adjustment } \\
\text { Line air leaks } \\
\text { Line chaffing } \\
\text { Gladhand leak } \\
\text { Oil contamination } \\
\text { Inoperative } \\
\text { Chamber moisture } \\
\text { Loose jamnut } \\
\text { Yoke not attached to pushrod } \\
\text { Exposed service/emergency hose } \\
\text { Air line kink }\end{array}$ & $\begin{array}{l}6 \\
6\end{array}$ & $\begin{array}{l}1 \\
1\end{array}$ & $\begin{array}{r}13 \\
8 \\
6 \\
6 \\
2 \\
1 \\
1 \\
1 \\
1 \\
2\end{array}$ & $\begin{array}{r}13 \\
8 \\
6 \\
3 \\
2 \\
1 \\
1 \\
1 \\
2\end{array}$ \\
\hline $\begin{array}{l}\text { Lights } \\
\text { Turn signal } \\
\text { Clearance light } \\
\text { Stop light } \\
\text { Tail light } \\
\text { Turn, hazard, brake inoperative }\end{array}$ & $\begin{array}{l}5 \\
2\end{array}$ & 4 & $\begin{array}{l}1 \\
1 \\
1\end{array}$ & $\begin{array}{l}5 \\
1 \\
1\end{array}$ \\
\hline $\begin{array}{l}\text { Driver } \\
\text { Log book } \\
10 \text { hour rule } \\
\text { Trip report } \\
\text { Permit } \\
\text { Missing document/number }\end{array}$ & $\begin{array}{r}19 \\
5 \\
1 \\
1 \\
3\end{array}$ & & & \\
\hline $\begin{array}{l}\text { Wheels/Tires } \\
\text { Tire depth } \\
\text { Tire cut/split/puncture } \\
\text { Loose rim } \\
\text { Cracked wheel } \\
\text { Loose bolt } \\
\text { Flat tire } \\
\text { Tire air leak } \\
\text { Tire missing tread }\end{array}$ & 3 & $\begin{array}{l}1 \\
1\end{array}$ & $\begin{array}{l}1 \\
2 \\
1 \\
1 \\
1\end{array}$ & $\begin{array}{l}1 \\
2 \\
1 \\
1 \\
1 \\
1 \\
1\end{array}$ \\
\hline $\begin{array}{l}\text { Miscellaneous } \\
\text { Broke/loose/missing part } \\
\text { Fuel tank hole/cap off } \\
\text { Defroster fan inoperable } \\
\text { Oil in engine area } \\
\text { Tie down } \\
\text { Placard } \\
\text { Loose turnbuckle at cask connection } \\
\text { Loose bolts } \\
\text { Dead battery } \\
\text { Loose shock absorber } \\
\text { Unprotected quick release } \\
\text { Exposed steering hose } \\
\text { Engine oil leak } \\
\text { Exhaust leak } \\
\end{array}$ & $\begin{array}{l}1 \\
1 \\
1 \\
3 \\
1 \\
1\end{array}$ & 2 & $\begin{array}{l}1 \\
1 \\
6 \\
1\end{array}$ & $\begin{array}{l}2 \\
1 \\
1 \\
6 \\
1\end{array}$ \\
\hline TOTALS & 72 & 11 & 54 & 65 \\
\hline Total Number of Inspections $=363$ & & & & \\
\hline
\end{tabular}


Rank of Out-of-Service Violations and All Violations: Table 14 presents a summary of the enhanced inspection violation data given in Table 13 with respect to the top 10 most frequently occurring defects/violations for out-of-service violations and for all violations. The most frequently occurring defect/violation (i.e., rank $=1$ ) for out-of-service violations is "brakes out of adjustment" and for all violations it is "driver log book" violations. In general brake related violations account for $69 \%$ of the top 10 out-of-service violations and $46 \%$ of the top 10 of all violations.

Table 14. Overall rank of violations by description and type of violation

\begin{tabular}{l|c|c|c|c}
\hline \multirow{2}{*}{$\begin{array}{c}\text { Description of } \\
\text { Defect/Violation }\end{array}$} & \multicolumn{2}{|c|}{$\begin{array}{c}\text { Out-of-Service } \\
\text { Violations }\end{array}$} & \multicolumn{2}{c}{$\begin{array}{c}\text { All } \\
\text { Violations }\end{array}$} \\
\cline { 2 - 5 } & Number of & Rank & Number of & Rank \\
\hline Brakes out of adjustment & 13 & 1 & 13 & 3 \\
Brakes - line air leaks & 8 & 2 & 14 & 2 \\
Brakes - gladhand leak & 6 & 3 & 6 & 5 \\
Placard & 6 & 3 & 7 & 4 \\
Turn signal & 5 & 5 & 5 & 7 \\
Brakes - oil contamination & 2 & 6 & & \\
Brakes inoperative & 2 & 7 & & \\
Brakes - exposed service/emergency hose & 2 & 7 & & \\
Tire cut/splitpuncture & 2 & 7 & 5 & 7 \\
Fuel tank hole/cap off & 2 & 7 & 19 & 1 \\
Driver log book & & & 6 & 5 \\
Brakes - line chaffing & & & 5 & 7 \\
Clearance light & & & 5 & 7 \\
Driver 10 hour rule & & & \\
\hline \hline
\end{tabular}

Comparison by Location of Inspection: Table 15 presents a summary of the enhanced inspection violation data with respect to where the inspections took place (i.e., point of origin, en route, or point of destination) for those inspections in which the inspection location is known (the location of the inspection could not be determined for 12 of the WIPP inspections). It is noteworthy that approximately $60 \%$ of the North American Standard and Enhanced North American Standard out-of-service violations were identified at the point of origin inspections. 
Table 15. Overall summary of violations by location of inspection and type of violation

\begin{tabular}{|c|c|c|c|c|}
\hline \multirow[b]{2}{*}{$\begin{array}{c}\text { Description of } \\
\text { Defect/Violation }\end{array}$} & \multirow[b]{2}{*}{$\begin{array}{l}\text { Not Out-of- } \\
\text { Service } \\
\text { Violations }\end{array}$} & \multicolumn{3}{|c|}{ Out-of-Service Violations } \\
\hline & & $\begin{array}{c}\text { North } \\
\text { American } \\
\text { Standard }\end{array}$ & $\begin{array}{l}\text { Enhanced } \\
\text { North } \\
\text { American } \\
\text { Standard }\end{array}$ & $\begin{array}{l}\text { Total Out-of- } \\
\text { Service }\end{array}$ \\
\hline Point of Origin & 17 & 6 & 32 & 38 \\
\hline En Route & 11 & 4 & 11 & 15 \\
\hline Point of Destination & 44 & 1 & 11 & 12 \\
\hline TOTALS & 72 & 11 & 54 & 65 \\
\hline Total Number of Inspections $=351$ & & & & \\
\hline
\end{tabular}

Comparison with SAFER Data: The Safety and Fitness Electronic Records (SAFER) System (available on the Internet at http://www.safersys.org) provides varied information on carriers including roadside out-of-service inspection information. In order to compare the enhanced inspection violation data with the SAFER System data it is necessary to identify each enhanced inspection as falling into one of three mutually exclusive categories for out-of-service violations: (1) no out-of-service violations identified, (2) one or more Enhanced North American Standard out-of-service violations identified (with or without any North American Standard out-of-service violations), or (3) one or more North American Standard-only out-of-service violations identified. Table 16 presents these data for each of the three carriers involved in the shipments as well as the overall totals.

Overall out of the 363 inspections, $2 \%$ (or 8 ) resulted in the vehicle being placed out of service under the North American Standard criteria, 13\% (or 49) resulted in the vehicle being placed out of service under the Enhanced North American Standard criteria, and a total of $16 \%$ (or 57) resulted in the vehicle being placed out-of-service. For comparison purposes the SAFER database shows that the 1997 National Average (percentage of all inspections conducted in the USA that resulted in an out-of-service status for the year 1997) is $25 \%$. Thus, compared to the national average the enhanced inspections have a much lower out-of-service violation rate.

According to the SAFER database, the percentage of vehicle inspections which resulted in an out-of-service status for the 24 months prior to 5/1/1999 for each of the carriers A, B, and $C^{6}$ are $15 \%, 9 \%$, and $12 \%$, respectively. From the information in Table 16 the comparable percentages for the North American Standard out-of-service status for the DOE radioactive shipments are $3 \%$ (2 out of 59 inspections) for Carrier A, $0 \%$ for Carrier $\mathrm{B}$, and $3 \%$ (6 out of 217 inspections) for Carrier C. The percentage for the Enhanced North American Standard out-of-service status is about the same for Carrier A (14\% - 8 out of 59 inspections), lower for Carrier B ( $2 \%-2$ out of 87 inspections), and higher for

\footnotetext{
${ }^{6}$ The three carriers involved in the 363 inspections are identified in this report as Carrier A, Carrier B, and Carrier C.
} 
Carrier C (18\% - 39 out of 217 inspections). The percentage for any out-of-service violation status is about the same for Carrier A (17\% - 10 out of 59 inspections), lower for Carrier B ( $2 \%$ - 2 out of 87 inspections), and much higher for Carrier C (21\% - 45 out of 217 inspections).

Table 16. Number of enhanced inspections by carrier and most severe violation type found

\begin{tabular}{|c|c|c|c|c|c|}
\hline \multirow[b]{2}{*}{ Carrier } & \multirow[b]{2}{*}{$\begin{array}{c}\text { Number } \\
\text { of } \\
\text { Inspections }\end{array}$} & \multirow[b]{2}{*}{$\begin{array}{c}\text { Number with } \\
\text { No Out-of- } \\
\text { Service } \\
\text { Violations }\end{array}$} & \multicolumn{3}{|c|}{ Out-of-Service Violations } \\
\hline & & & $\begin{array}{l}\text { Number } \\
\text { with only } \\
\text { North } \\
\text { American } \\
\text { Standard }\end{array}$ & $\begin{array}{l}\text { Number with } \\
\text { Enhanced } \\
\text { North } \\
\text { American } \\
\text { Standard } \\
\end{array}$ & $\begin{array}{c}\text { Number with } \\
\text { any } \\
\text { Out-of-Service }\end{array}$ \\
\hline A & 59 & 49 & 2 & 8 & 10 \\
\hline B & 87 & 85 & 0 & 2 & 2 \\
\hline C & 217 & 172 & 6 & 39 & 45 \\
\hline TOTALS & 363 & 306 & 8 & 49 & 57 \\
\hline $\begin{array}{l}\text { Percentage of } \\
\text { Total Number of } \\
\text { Inspections ( } 363 \text { ) }\end{array}$ & & $84 \%$ & $2 \%$ & $13 \%$ & $16 \%$ \\
\hline
\end{tabular}

\section{CONCLUSIONS}

This report provides a brief summary of selected results to date from the Pilot Study data collection activities. It is primarily focussed on presenting basic characterization and comparison information about the inspection form data. Using this information, as well as information from past analyses and experiences (e.g., reports on the Cesium and LSA/Nitric Acid campaigns, discussions with inspectors and drivers, etc.) the following are conclusions formulated in specific areas of interest to the study.

\section{En Route Inspection}

From the sparse data obtained in the Pilot Study on the reported shipping campaigns (i.e., the Cesium, LSA/Nitric Acid, Brookhaven - Savannah River, Oak Ridge - Savannah River, and WIPP shipments), it is the considered opinion of CVSA that only a limited number of en route inspections mandated by select state statutes is necessary in a shipping campaign which falls under the Enhanced North American Standard. It was also determined that after jurisdictions recognized what the ENAS procedures are and what they assure, they were receptive to granting reciprocity to a motor carrier displaying a CVSA enhanced decal, thereby expediting the shipment.

\section{Point of Origin Inspection}

The violations found at the point of origin were significant, however they were corrected prior to departure. The shipments arrived at the point of destination generally intact and with only few violations. The "defect free" requirement under the ENAS has proven to be a valuable tool in the Pilot Study by ensuring that the vehicle, driver, and cargo begin their 
movement in a safe manner and that they will arrive at their destination with only minor or no safety violations.

\section{Uniformity and Reciprocity}

Uniformity and reciprocity were generally followed by all the involved states during the Pilot Study. In the LSA/Nitric Acid campaign, a uniformity problem developed pertaining to regulation interpretations. With respect to reciprocity, there was a good mix of state inspections and states that honored the decal. Some states are required by state statute to stop and inspect the radioactive material shipments and in some instances must escort the shipment within their state.

Inspector training needs to be addressed in order to obtain uniformity of enforcement. This is especially the case in the areas of markings and labeling.

\section{Carriers}

Generally the carriers need to address brake maintenance, especially relating to brake adjustment.

In certain instances the carriers need to address hours of service violations and ensure that their drivers are cognizant of the regulations in this area.

The maintenance of placards needs to be addressed by the carriers to ensure that the placards on their vehicles are readable and well kept. As a standard for operation, the carriers should carry extra, appropriate placards in their vehicles in the event of damage or if a placard becomes unreadable.

The results from this Pilot Study are not definite enough to make a determination that there should be a change in or elimination of any specific carrier. More data is needed to obtain significant results that would indicate an appropriate curtailment action.

The carriers involved in this Pilot Study were very responsive to correcting any deficiencies and were very cooperative with the state inspectors and staff of CVSA.

\section{Data Quality}

Because there was a reduction in funds to support the Pilot Study as it was initially designed, several of the data quality assurance features were not implemented. In particular the inspection forms were not reviewed as they were received to check for incompletely filled fields, inconsistencies, and other problems (e.g., incorrect radiological calculations). Also, there was generally no attempt to obtain missing inspection forms or find out why inspections were not done as planned or identify the location of an inspection (i.e., point of origin, en route, or point of destination). Consequently for this report there were several expected inspection forms missing and it was necessary to exclude some forms received because they were incomplete.

It was also found that if the inspections are part of an identified shipping campaign, then general knowledge about the campaign assists in maintaining the data quality. For 
example, certain items may be generally known about a shipping campaign such as the carrier, the locations of inspections, and the cargo so that if these items are incomplete or incorrect on the form then they can be readily fixed. However, for many of the forms received that are not associated with a known shipping campaign, without follow up it is often impossible to determine basic facts concerning the inspections if the forms are not well completed.

\section{RECOMMENDATIONS}

The following recommendations are based on the findings of the data collection efforts during the Pilot Study and the conclusions drawn from those findings. For the continuing viability of the enhanced inspection program and to insure safety and efficiency in the transportation of radioactive materials, it is recommended that

- Steps be taken to get a "buy-in" from shippers to include the enhanced inspection procedures in transportation plans and operations. A strong commitment is necessary in providing a viable and efficient enhanced inspection program. This was evident during the Cesium and LSA/Nitric Acid shipping campaigns.

- The enhanced inspection program should only be used on select shipments; e.g., highway route controlled quantity (HRCQ) shipments of radioactive material and special designated shipments such as WIPP. It should not be used on low level shipments such as the LSA/Nitric Acid shipments.

- The DOE continue to emphasize and include Point of Origin "defect free" inspections per the ENAS in the protocols being developed on all their HRCQ and transuranics (TRU) shipments in order to address public concerns regarding safety of these kinds of shipments.

- Periodic and random inspections be conducted at the point of destination of HRCQ radioactive shipments and other radioactive material shipments.

- The industry use equipment with automatic slack adjusters on braking systems for all shipments transporting HRCQ and TRU materials and that DOE build this requirement into contracts and tenders for highway shipments of HRCQ and TRU.

- The industry insure that the placards on their equipment are securely fastened and legible and that extra placards are carried inside the vehicle.

- Carriers involved in HRCQ and TRU shipments have their traffic managers, mechanics and drivers attend a CVSA industry awareness course on the Level I North American Standard (NAS) inspection program and Hazardous Materials and ENAS inspection program.

- Carriers shipping radioactive materials under the CVSA ENAS use dedicated and CVSA-trained drivers as it has been determined that such drivers have more understanding of and are responsive to the enhanced inspection process.

- More emphasis and resources be given on data collection and analysis as a means of providing input for changes in the enhanced inspection. Data collection includes conducting surveys of inspectors, obtaining data from the inspection and driver 
interview forms, and utilizing other sources of related transportation data (e.g., Safestat).

- Resources be provided to accommodate the follow-up necessary to correct deficiencies in reporting and identify enforcement inconsistencies and training needs.

- Methods continue to be pursued to integrate the enhanced inspection form with other inspection data collection systems to minimize the recording of identical information more than once and to take advantage of existing electronic means of data entry. 


\section{APPENDIX}

- CVSA/DOE Spent Fuel/Transuranic/High Level Radioactive Waste Pilot Study Inspection Form

- CVSAJDOE Pilot Inspection Study Point of Destination Driver Interview Form

- Inspections and Enforcement 
CVSA/DOE Spent Fuel/Transuranic/High Level Radioactive Waste Pilot Study Inspection Form

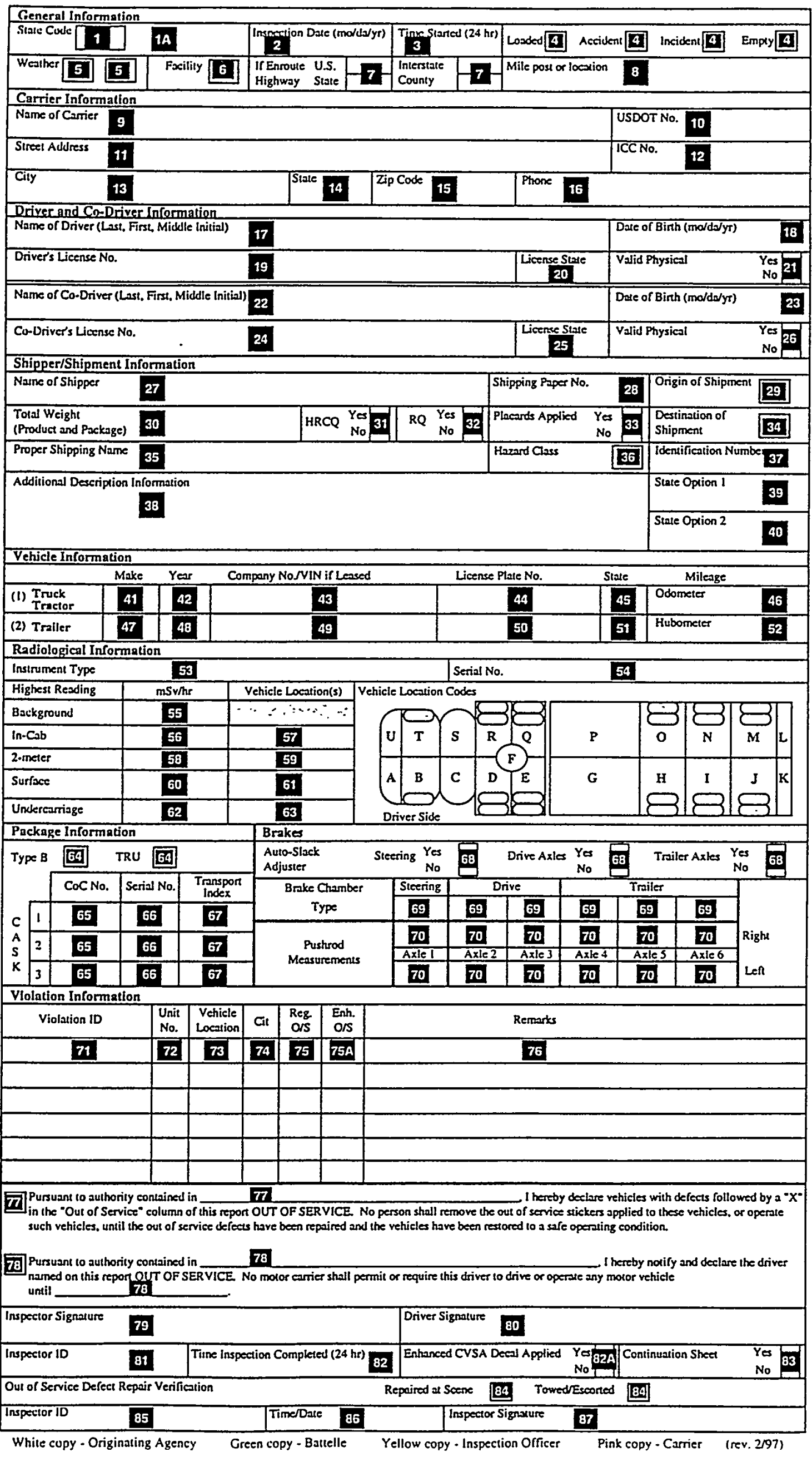


Violation Retuirements

If violations are noted on the reverse side, or on the continuation sheet the following requirements must be met:

1. All violations and defects are to be corrected or repaired.

2. The person completing "out of service" repairs must sign the form.

3. A company official must sign the form certifying compliance with federal and state motor carrier safety and hazardous materials regulations.

4. The form is to be mailed to the address stated below within 15 days from the date of inspection.

I certify that the violations listed in the "Violation Information" section have been satisfactorily repaired as of the date indicated.

\begin{tabular}{|l|l|l|}
\hline Signature of Person Completing Repairs & Name of Shop (Garage) & Date \\
\hline $\begin{array}{l}\text { The undersigned certifies that all violations noted on this report have been corrected and action has been taken to } \\
\text { assure compliance with the federal and state motor carrier safety and hazardous material regulations insofar as they are } \\
\text { applicable to motor carriers and drivers. I understand that failure to comply will subject me to additional violations } \\
\text { under the regulations noted. }\end{array}$ & Title & Date \\
\hline Carrice Orficial Signature &
\end{tabular}

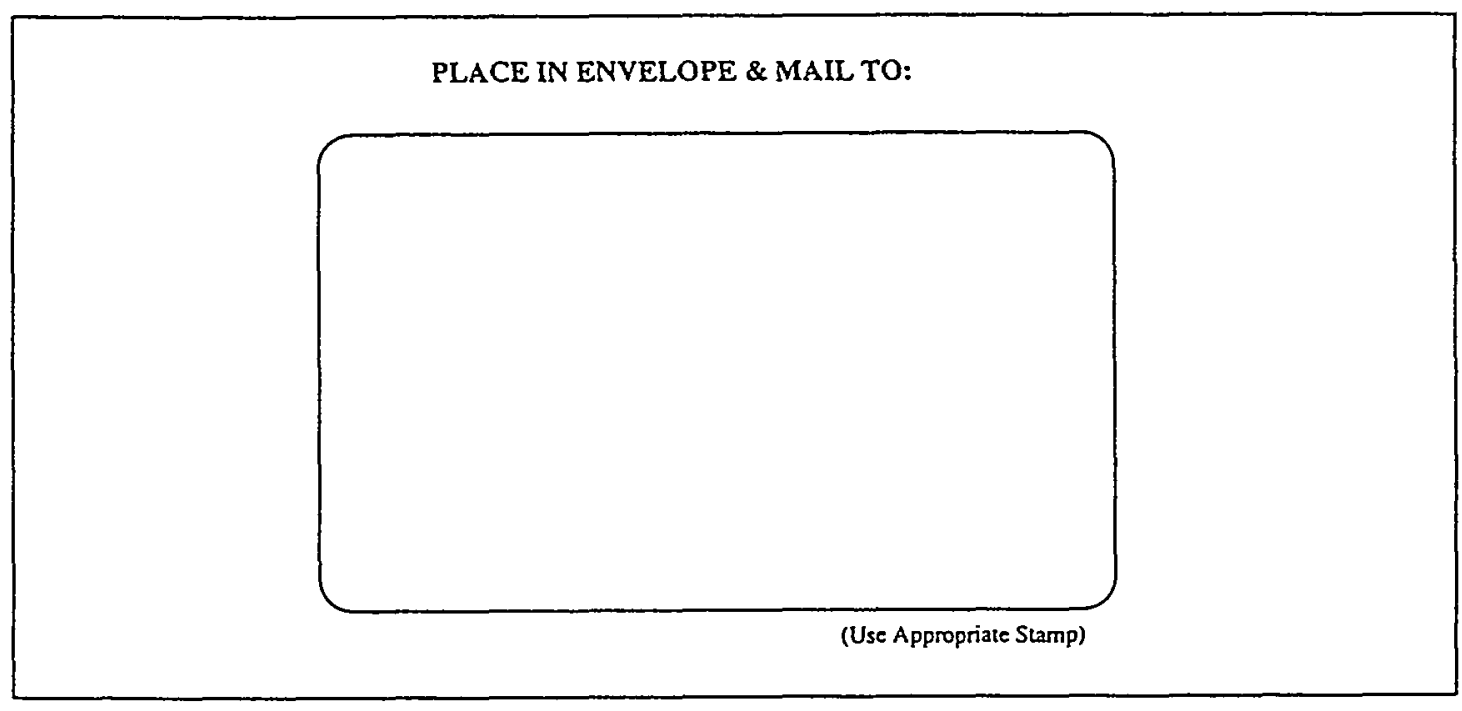

\begin{tabular}{|c|c|c|}
\hline Code Information & & \\
\hline Weather & & Facility/Origin/Destination \\
\hline $\begin{array}{l}1=\text { Clear } \\
2=\text { Rain } \\
3=\text { Snow/lce/Sleet } \\
4=\text { High Wind }\end{array}$ & $\begin{array}{l}5=\text { Fog } \\
6=\text { Dust } \\
7=\text { Cloudy }\end{array}$ & $\begin{array}{l}1=\text { INEL } \\
2=\text { Hanford } \\
3=\text { Rocky Flats } \\
4=\text { WIPP Facility } \\
5=\text { Enroute } \\
6=\text { Fort SL Vrain } \\
7=\text { IOTECH }\end{array}$ \\
\hline & & $8=$ \\
\hline
\end{tabular}


CVSA/DOE Spent Fuel/Transuranic/High Level Radioactive Waste Pilot Study Inspection Form CONTINUATION FORM

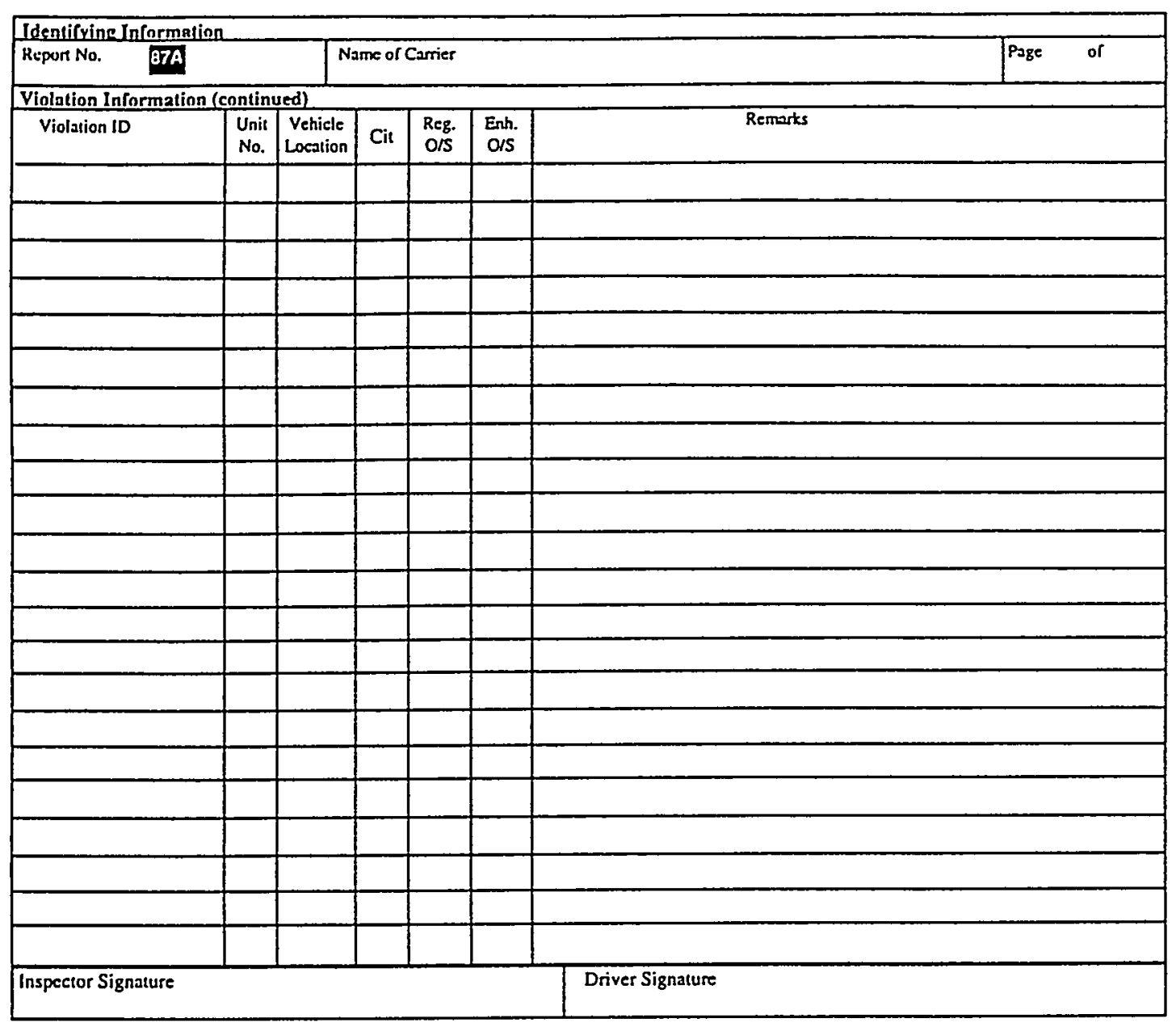

Lessor Information, If Applicable

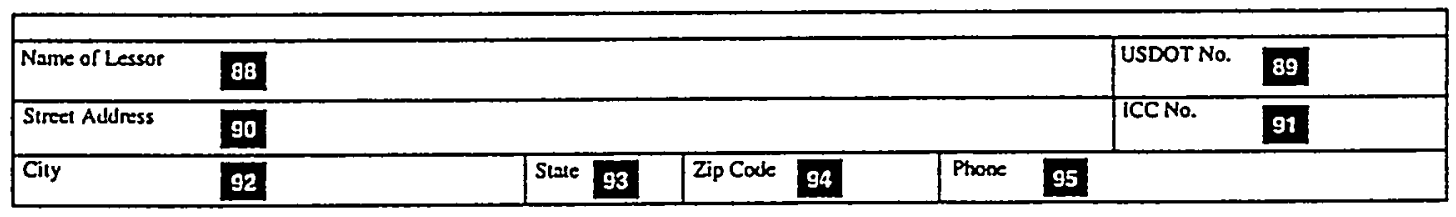

Comments

\section{6}




\section{HOW TO COMPLETE \\ INSPECTION FORM DATA ELEMENTS}

\section{General Information}

1. STATE CODE - Enter 2-character state code (e.g., CO, ID, WA, etc.).

1A. REPORT NO. - Preprinted 5-digit number.

2. INSPECTION DATE - Enter date of inspection using month, day, year (mo/da/yr) format.

3. TIME STARTED - Enter start time of inspection in 24 hour format.

4. LOADED/ACCIDENT/INCIDENT/EMPTY - Place an "X" in the appropriate box(s). (At least one box must be checked.)

5. WEATHER - Enter the appropriate weather code from the rear of the inspection form. Include up to 2 multiple weather codes when appropriate.

6. FACILTY - Enter the appropriate code from the rear of the inspection form. (If code is not on back, use code \#8 and enter facility name on back of form.)

7. IF ENROUTE HIGHWAY - Enter highway number in the appropriate highway type block to identify highway at the location of inspection.

8. MILE POST OR LOCATION - Enter nearest Mile Post number or identify the name of, and the direction and distance from, the nearest city or town, e.g., 2.5 miles N.W. of Laramie.

\section{Carrier Information}

9. NAME OF CARRIER - Enter carrier's full business name, e.g., Tri-State Motor Transit Co.

(CAUTION: ensure you use the full and correct name for the carrier performing the transportation.)

10. USDOT NO. - Enter USDOT No. when applicable. (Applies only to a Private Carrier.)

11. STREET ADDRESS - Enter a physical address for carrier's principal place of business. (NOTE: P.O. Box numbers are not acceptable.)

12. ICC NO. - Enter the ICC docket number, when applicable.

13. CITY - Enter full name of city.

14. STATE - Enter approved 2 character state abbreviation.

15. ZIP CODE - Enter 5 or 9 digit Zip Code.

16. PHONE - Enter carrier phone number, including area code. 


\section{Driver and Co-Driver Information}

17. NAME OF DRIVER - Enter driver's last name, first name, and middle initial.

18. DATE OF BIRTH - Enter driver's date of birth using the month, day, year (mo/da/yr) format.

19. DRIVER'S LICENSE NO. - Enter complete driver's license number.

20. LICENSE STATE - Enter approved 2 character state abbreviation for state issuing license.

21. VALID PHYSICAL - Place an " $X "$ in the yes box or no box to indicate whether or not the medical certificate is valid.

22. NAME OF CO-DRIVER - Enter co-driver's last name, first name, and middle initial.

23. DATE OF BLRTH - Enter co-driver's date of birth using the month, day, year (mo/da/yr) format.

24. CO-DRIVER'S IICENSE NO. - Enter complete co-driver's license number.

25. LICENSE STATE - Enter approved 2 character state abbreviation for state issuing license.

26. VALID PHYSICAL - Place an " $X "$ in the yes box or no box to indicate whether or not the medical certificate is valid.

\section{Shipper/Shipment Information}

27. NAME OF SHIPPER - Enter shipper's full business name as shown on the shipping document.

28. SHIPPING PAPER NO. - Enter the document number of the shipping document.

29. ORIGIN OF SHIPMENT - Enter the appropriate code from the rear of the inspection form. (If code is not on back, use code \#8 and enter origin name on back of form.)

30. TOTAL WEIGHT - Enter the total combined weight of the product and package, as entered on the shipping document.

31. HRCQ - Place an " $X$ " in the yes box or no box to indicate whether or not the material is classified as a Highway Route Controlled Quantity.

32. RQ - Place an "X" in the yes box or no box to indicate whether or not the material is classified as a Reportable Quantity.

33. PLACARDS APPLIED - Place an " $X "$ in the yes box or no box to indicate whether or not placards are applied.

34. DESTINATION OF SHIPMIENT - Enter the appropriate code from the rear of the inspection form. (If code is not on back, use code \#8 and enter destination name on back of form.)

35. PROPER SHIPPING NAME - Enter proper shipping name of material as recorded on the shipping document.

36. HAZARD CLASS - Preprinted number " 7 " for the international hazard class code for radioactive materials. 
37. IDENTIFICATION NUMBER - Enter the identification number for the material as entered on the shipping document.

38. ADDITIONAL DESCRIPTION INFORMATION - Provide any additional information regarding the shipment in this block.

39. STATE OPTION I - Space reserved for state use.

40. STATE OPTION 2 - Space reserved for state use.

\section{Vehicle Information}

41. MAKE - Enter MCSAP code for "Truck Tractor" make or manufacturer.

42. YEAR - Enter year of "Truck Tractor" manufacture.

43. COMPANY NO./VIN IF LEASED - Enter company (Unit) number or vehicle identification number (VIN) as applicable.

44. LICENSE PLATE NUMBER - Enter "Truck Tractor" license (Base) plate number.

45. STATE - Enter approved 2 character state abbreviation for state issuing license.

46. MILEAGE - Enter vehicle's actual "Odometer" mileage.

47. MAKE - Enter MCSAP code for "Trailer" make or manufacturer.

48. YEAR - Enter year of "Trailer" manufacture.

49. COMPANY NO./VIN IF LEASED - Enter company (Unit) number or vehicle identification number (VIN) as applicable.

50. LICENSE PLATE NUMBER - Enter "Trailer" license (Base) plate number.

51. STATE - Enter approved 2 character state abbreviation for state issuing license.

52. MILEAGE - Enter vehicle's actual "Hubometer" mileage.

\section{Radiological Information}

53. INSTRUMENT TYPE - Enter the name and model of the monitoring instrument.

54. SERIAL NO. - Enter the serial number of the monitoring instrument.

55. BACKGROUND - Enter the highest $\mathrm{mSv} / \mathrm{hr}$ value obtained during a survey of the inspection site. (NOTE: Survey should be completed prior to arrival of shipment.) If readings are not in mSv/hr then cross out the "mSv/hr" heading at the top of the column and write in the particular units of measurement to indicate that the readings are in units other than $\mathrm{mSv} / \mathrm{hr}$.

56. IN CAB - Enter the highest $\mathrm{mSv} / \mathrm{hr}$ value obtained during a survey within the cab area occupied by the driver. 
57. VEHICLE LOCATION(S) - Enter the location(s) of the highest $\mathrm{mSv} / \mathrm{hr}$ value obtained using the Vehicle Location Codes provided in the diagram on the Inspection Form.

58. 2 METER - Enter the highest $\mathrm{mSv} / \mathrm{hr}$ value obtained during a survey of the vehicle at a distance of 2 meters $\left(6.6^{\prime}\right)$.

59. VEHICLE LOCATION(S) - Enter the location(s) of the highest $m S v / h r$ value obtained using the Vehicle Location Codes provided in the diagram on the Inspection Form.

60. SURFACE - Enter the highest $\mathrm{mSv} / \mathrm{hr}$ value obtained using the survey instrument at the surface of the package/vehicle. (Based on type of load configuration).

61. VEHICLE LOCATION(S) - Enter the location(s) of the highest mSv/hr value obtained using the Vehicle Location Codes provided in the diagram on the Inspection Form.

62. UNDERCARRIAGE - Enter the highest $\mathrm{mSv} / \mathrm{hr}$ value obtained during a survey of the undercarriage of the vehicle.

63. VEHICLE LOCATION(S) - Enter the location(s) of the highest $\mathrm{mSv} / \mathrm{hr}$ value obtained using the Vehicle Location Codes provided in the diagram on the Inspection Form.

\section{Package Information}

64. PACKAGE INFORMATION - Place an " $X "$ in the appropriate box.

65. COC NO. - Enter the Certificate of Compliance number as shown on the shipping document or the package.

66. SERLAL NO. - Enter the serial number as shown on the shipping document or the package.

67. TRANSPORT INDEX - Enter the transport index as shown on the shipping document and the label applied to the package.

\section{Brakes}

68. BRAKES - Indicate the presence of automatic slack adjusters used on the steering, drive and trailer axles by placing a " $X$ " in the appropriate yes or no boxes.

69. BRAKE CHAMBER TYPE - Enter the brake chamber type number (e.g., 16, 20, 24, etc.) for each axle.

70. PUSHROD MEASUREMENT - Enter actual pushrod travel measurement for the brake chambers on each axle. 


\section{Violation Information}

71. VIOLATION ID. - Enter the appropriate "SAFETYNET" violation code for each violation.

72. UNIT NO. - Enter the number "1" (Truck Tractor), "2" (Trailer), or "D" (Driver) from the Vehicle Information block for each violation.

73. VEFICLE LOCATION - Enter the appropriate Vehicle Location Code from the diagram on the Inspection Form for each violation.

74. CIT - Place an " $X "$ in this block for violations where a citation was issued.

75. REG. O/S - Place an " $X "$ in this block for each violation when the vehicle is placed out-of-service according to the regular North American Standard out-of-service criteria.

75A. ENH. O/S - Place an " $X "$ in this block for each violation when the vehicle is placed out-of-service according to the enhanced North American Standard out-of-service criteria.

76. REMARKS - Enter remarks for each violation when appropriate. Also write in "enhanced" if an outof-service violation is an enhanced out-of-service violation.

\section{Out-of-Service}

77. VEHICLE OUT-OF-SERVICE - Place an " $X$ " in the box to identify when a vehicle is placed "Out-ofService". Enter the applicable statutory (State) reference authorizing the "Out-of-Service" action.

78. DRIVER OUT-OF-SERVICE - Place an " $X$ " in the box to identify when the driver is placed "Out-ofService". Enter the applicable statutory (State) reference authorizing the driver to be placed "Out-ofService". Also, enter the actual date and time the driver is permitted to retum to duty.

\section{Signature Blocks}

79. INSPECTOR SIGNATURE - Original signature of the official performing the inspection.

80. DRIVER SIGNATURE - Original signature of driver.

81. INSPECTOR ID - Enter personnel number or badge number of official performing the inspection.

82. TIME INSPECTION COMPLETED - Enter the time the inspection was completed using the 24 hour format.

82A. ENHANCED CVSA DECAL APPLIED - Place an " $X$ " in the yes box or no box to indicate whether or not an enhanced CVSA decal is being applied.

83. CONTINUATION SHEET - Place an " $X "$ in the appropriate yes or no box. 


\section{Defect Repair Verification}

84. OUT-OF-SERVICE DEFECT REPAIR VERIFICATION - Place an " $X$ " in the appropriate box. (At least one box must be checked.)

85. INSPECTOR ID - Enter personnel number or badge number of official signing repair verification.

86. TIME/DATE - Enter time and date using 24 hour and mo/da/yr format.

87. INSPECTOR SIGNATURE - Original signature of the official verifying defect repair.

\section{Continuation Information}

87A. REPORT NO. - Enter the 5-digit report number that is preprinted on the front page of the main inspection form.

\section{Lessor Information}

88. NAME OF LESSOR - Enter lessor's full business name, e.g., Tri-State Motor Transit Co. (CAUTION: ensure you use the full and correct name for the lessor performing the transportation.)

89. USDOT NO. - Enter USDOT No. when applicable. (Applies only to a Private Lessor.)

90. STREET ADDRESS - Enter a physical address for lessor's principal place of business. (NOTE: P. O. Box numbers are not acceptable.)

91. ICC NO. - Enter the ICC docket number, when applicable.

92. CITY - Enter full name of city.

93. STATE - Enter approved 2 character state abbreviation.

94. ZIP CODE - Enter 5 or 9 digit Zip Code.

95. PHONE - Enter lessor phone number, including area code.

96. COMMENTS - Enter any other comments. 
WIPP SHIPMENTS

CVSA/DOE POINT OF DESTINATION DRIVER INTERVIEW

For each trip please complete this form at the point of destination and mail it to:

Toni Slavich, Battelle Seattle Research Center, 4500 Sand Point Way NE, Seattle, WA 98105-3900

\section{General Information}

Driver 1: Name

Driver 2: Name

Date Time

Location

\section{CVSA/DOE Inspections}

Number of standard CVSA inspections:

States which inspected:

Was standard CVSA decal affixed at point of origin? NO YES.

States which honored standard CVSA decal and did not inspect (e.g., UT, WY, etc.):

Number of enhanced (radiological) CVSA/DOE inspections: States which inspected:

Was enhanced CVSA decal affixed at point of origin? NO YES.

States which honored enhanced CVSA decal and did not inspect (e.g., UT, WY, etc.):

Were there any problems with any of the inspections? $\mathrm{NO}$ YES. If YES, explain

\section{Events or Problems}

Did any of the following significant events or problems arise during the course of the trip? If YES, please describe on the back of this form each event or problem, the location, and what you think caused the problem or event, why you think the problem or event happened, and whether you got the help you needed to address or resolve the problem.

Were there any roadway "trouble spots" (grades, difficult entrances or weaves, poor road surfaces, etc.)?

Were there any extreme weather conditions?

Was there any unexpected road construction?

Were you directed to use an alternate route during this trip?

Did you have to make any special driving maneuvers to avoid an accident or near miss?

Did you have to use a safe parking area?

Were there any mechanical or equipment problems?

Were there any communications (e.g., TRANSCOM) problems?

Were there any other problems, inconveniences, or delays (demonstrations, accidents, traffic congestion, etc.)?

$\underline{\text { NO }} \quad \underline{\text { YES }}$

Was there any additional information that would have helped you make this trip uneventful? 
If any yes responses, please explain:

Problem/event \#1

Location

Cause/reason

Did you get the help you needed?

Problem/event \#2

Location

Cause/reason

Did you get the help you needed?

Do you have any other comments about events or problems on this trip?

\section{Other Comments}

Do you have any other observations or comments about the transport of radioactive materials? 


\section{WIPP Shipments \\ CVSA/DOE Point of Destination Driver Interview Form \\ Distribution Instructions}

1. For each shipment give the drivers of the vehicle one form.

2. Tell the drivers that they may fill out the form as events occur along the route, but they should finish the form and mail it after they reach the point of destination.

3. If you have any questions or need more forms, please contact Toni Slavich at 206528-3266. 


\section{Inspections and Enforcement}

\section{Inspections}

The CVSA through its committees and by approval of its membership have developed six levels of safety inspections for jurisdictional inspectors to use in inspecting motor carriers traversing the highways or at their individual carrier facilities. The inspection criteria is based on requirements in the U.S. Department of Transportation regulation Title 49 CFR. The following is a brief summary of these levels:

Level 1-North American Standard Inspection: Inspections which include examination of the driver's credentials and major equipment items which have been determined to have a potential for causing an accident.

Level II-Walk-Around Driver/Vebicle Inspection: Inspections that include each of the items specified in the North American Standard, however it is contemplated that this inspection will include items which can be inspected without physically getting under the vehicle.

Level III-Driver-Only Inspection: A roadside inspection which examines the driver's credentials.

Level IV-Special Inspections. Inspections under this heading include a one-time examination of a particular item and are generally used for special studies.

Level V-Vehicle-Only Inspections. Inspections that include each of the vehicle inspection items as specified under the North American Standard without a driver present.

Level VI-Enhanced North American Standard for Radiological Shipments. Inspections of select radiological shipments which include inspection procedures, enhancements to the Level I inspection, radiological requirements, and the enhanced out-of-service criteria. Select radiological shipments include only highway route controlled quantities as defined by Title 49 Section 173.403, and transuranics.

\section{Enforcement}

Inspectors take enforcement action as determined by regulation, training, authority, department guidelines, and officer discretion. A violation may be noted and acted upon by a notation on the inspection report, placing the vehicle out of service, arrest, citation, verbal warning or a combination of these actions.

\section{Violations noted on the inspection report}

Notation of a violation on the inspection report indicates that a violation of the law or regulation (federal, state, or local jurisdiction) has been detected and must be rectified or repaired. The seriousness of the violation will determine if the motor carrier is allowed to proceed or is placed out of service. 


\section{Out-of-service criteria}

The out-of-service criteria is enacted when a violation on the motor carrier meets the strict CVSA criteria for placing a motor carrier out of service either by the North American Standard or by the Enhanced North American Standard.

The North American Standard Out-of-Service Criteria is a well-defined set of violations which have been cited as having the potential for causing an accident.

The Enbanced North American Standard Out-of-Service Criteria include all of the North American Standards with stricter or additional requirements, as well as other more stringent requirements, which the CVSA membership believes are necessary for a transporter of highway route controlled quantities of radioactive materials and transuranic waste.

With either standard it is necessary that the motor carrier correct the deficiency before proceeding. 